\title{
Improved SI Engine Efficiency using Acetone-Butanol-Ethanol (ABE)
}

\author{
Karthik Nithyanandan ${ }^{1}$, Jiaxiang Zhang ${ }^{1,2}$, Yuqiang $\mathrm{Li}^{1,3}$, Han $\mathrm{Wu}^{1,4}$, Timothy H. Lee ${ }^{1}$, \\ Yilu Lin ${ }^{1}$, Chia-fon F. Lee ${ }^{1,4}$ \\ ${ }^{1}$ Department of Mechanical Science and Engineering, University of Illinois at Urbana- \\ Champaign, IL 61801, USA \\ ${ }^{2}$ School of Energy and Power Engineering, Xi'an Jiaotong University, Xi'an, Shaanxi, \\ China \\ ${ }^{3}$ Central South University, China \\ ${ }^{4}$ School of Mechanical Engineering, Beijing Institute of Technology, Beijing, China
}

Corresponding author: Chia-fon F. Lee Tel.: 1-217-3335879; Fax: 1-217-2446534; Email address:cflee@illinois.edu.

Abstract

Alcohols, especially n-butanol, have received a lot of attention as potential fuels and have shown to be a possible alternative to pure gasoline. The main issue preventing butanol's use in modern engines is its relatively high cost of production. ABE, the intermediate product in the $\mathrm{ABE}$ fermentation process for producing bio-butanol, is being studied as an alternative fuel because it not only preserves the advantages of oxygenated fuels, but also lowers the cost of fuel recovery for individual component during fermentation. With the development of advanced $A B E$ fermentation technology, the volumetric percentage of acetone, butanol and ethanol in the biosolvents can be precisely controlled. In this respect, it is desirable to estimate the performance of different $\mathrm{ABE}$ blends to determine the best blend and optimize the production process accordingly. In this paper, pure ABE fuels with different component volumetric ratio, (A: B: E of 3:6:1, 6:3:1 and 5:14:1), were combusted in a naturally aspirated, port-fuel injected spark ignited engine. The performance of these blends was evaluated through measurements of in-cylinder pressure, and various exhaust emissions. In addition, pure gasoline and neat n-butanol were also tested as baselines for comparison of ABE fuels. The tests were conducted at an engine speed of Page 1 of 38 
1200 RPM and loads of 3 and 5 bar brake mean effective pressure (BMEP) under different equivalence ratios. On the basis of the experimental data, the combustion characteristics and emission behavior of these fuels have been presented and discussed. It was found that in terms of thermal efficiency, $\mathrm{ABE}(6: 3: 1)$ might be much better suited for use as an alternative fuel, relative to $\mathrm{ABE}(3: 6: 1)$ or n-butanol.

\section{Introduction}

In recent years, growing public concern over the economic and environmental viability of gasoline, diesel and other fossil fuels, has prompted the investigation into oxygenates as fuel additives [1]. Oxygenated compounds previously considered include butanol, ethanol, methanol, and methyl or ethyl esters or ethers [2]. Many research studies into n-butanol have been conducted due to its properties that closely resemble those of gasoline [2-4]. These properties include ease of transportation through pipelines due to its hydrophobic nature thereby resulting in a lower tendency to separate from the base fuel (i.e. diesel or gasoline) when mixed with water; an air fuel ratio that closely resembles that of gasoline allowing for greater percentages of butanol to be mixed with gasoline; and an energy content that is $30 \%$ more than ethanol $[5,6]$. Furthermore, n-butanol, when used as a transportation fuel, can save 39-56\% fossil energy while reducing greenhouse gas emissions by up to $48 \%$ on a lifecycle basis [6]. The main issue that prevents butanol's use in modern engines however is its relatively high cost of production, which has been the subject of many other research studies [5-16].

Acetone-butanol-ethanol (ABE) fermentation primarily involves bacterial fermentation of biomass feedstock to produce acetone, n-butanol and ethanol at volume percentages of approximately $22-33 \%, 62-74 \%$, and 1-6\% respectively (roughly a 3:6:1 ratio [16, 17]). Due to the depletion of fossil fuels, and subsequent rise in oil prices, interest in ABE production by fermentation as a viable alternative to the petroleum process has been renewed. Bio-butanol usually uses a strain of bacteria from the Clostridia Class (Clostridium Family). Clostridium acetobutylicum is the most well-known strain, although Clostridium beijerinckii has also been used for this process with good results. Clostridial species show promise for ABE fermentation using lignocellulosic (e.g., bagasse, barley straw, wheat straw, corn stover and switchgrass etc.) and non-cellulosic (e.g., glucose, corn, sago, and sugarcane) feedstocks. The United States 
produces the largest amount (approximately 280 million tons per year) of corn in the world, whereas China comes in second with approximately 131 million tons per year. From the availability point of view, the lignocellulosic materials have been marked as a cheaper and more abundant feedstock for biofuels [3]. If the intermediate product of fermentation, the $A B E$ mixture, could be used for clean combustion, the separation costs would be mitigated. This would save an enormous amount of time and money in the production chain of bio-butanol [8]. It should be noted that the actual fermentation product contains a relatively small amount of water ( $<0.5 \%$ by weight) [11], which has not been included in this study. This study of watercontaining $\mathrm{ABE}$ is being carried out and will be discussed in a future paper. However, this level of purity is sufficient for full miscibility with gasoline. ABE fuel properties can be adjusted to suit internal combustion engine requirements, by changing the ratio of the $\mathrm{ABE}$ components through fermentation. As mentioned earlier, the typical ratio of acetone, butanol and ethanol is 3:6:1 during the formation process, but this is adjustable. Modification of bacterial strains at the genetic level is the common method for researchers to optimize production components. At the same time, fermentation products and the ratio of their formation also vary with the fermentation conditions ( $\mathrm{pH}$, temperature, nutrients) [17]. The goal of this study is to investigate the combustion characteristics of $\mathrm{ABE}$ in a spark-ignited engine estimate the performance of different $\mathrm{ABE}$ blends to determine the best blend and optimize the production process accordingly. In the future, $\mathrm{ABE}$ mixture could be used directly, with the components ratios controlled during the $\mathrm{ABE}$ fermentation process $[18,19]$

Butanol has been widely investigated as an alternative fuel for both gasoline and diesel engines. Zheng et al. investigated the effects of n-butanol and its isomers on combustion and emissions of a diesel engine, and found that the alcohol blends showed a retarded combustion phasing, higher combustion efficiency and lower soot emissions. However, gaseous emissions were not affected obviously [20]. They also studied combustion and emission of blends of diesel, gasoline and n-butanol, and found that the ITE was slightly increased with the blended fuels [21]. Liu et al. studied the combustion of neat n-butanol and soybean biodiesel in a constant volume chamber and found that n-butanol was more effective in soot suppression relative to biodiesel [22]. They also studied n-butanol and biodiesel dual-fuel combustion in a diesel engine. A slightly higher ITE and significantly reduced NOx, soot emissions were observed [23]. Liu et 
al. also investigated the effect of adding various oxygenated fuels ( $20 \%$ by volume) to diesel fuel and found that among n-heptane, iso-octane, n-butanol and methyl octynoate, n-butanol showed the largest soot reduction, however, they found that fuel properties and oxygenated structures had minor effects on gaseous emissions and ITE [24]. As for SI engines, Masum et al. [25] studied the combustion and emissions of methanol, ethanol, butanol and pentanol blended with $80 \%$ vol. gasoline. They found that all alcohol blends displayed better engine torque and lowered emissions relative to gasoline. Costagiola et al. [26] studied performance and emissions of various gasoline/alcohol blends. They found an increase in global efficiency and a reduction in emissions using the blends. Williams et al. [27] investigated a series of conventional and alcohol fuels and concluded that thermal efficiency, combustion, and emissions were not adversely affected as a result of adding any butanol to gasoline. Dernotte et al. [28] evaluated the combustion and emissions characteristics of butanol-gasoline blends in a port fuel injection (PFI) SI engine. The results demonstrated that a $40 \%$ butanol/60\% gasoline blend by volume minimized $\mathrm{HC}$ emissions and no significant change in $\mathrm{NO}_{\mathrm{x}}$ emissions were observed with the exception of the $80 \%$ butanol $/ 20 \%$ gasoline blend. The addition of butanol improved combustion stability and reduced ignition delay (0-10\% MFB). The change of specific fuel consumption of B40 blend was within $10 \%$ of that of pure gasoline for stoichiometric mixture. Wigg et al. [29] showed that blends containing below $40 \%$ volume of butanol offered similar unburned hydrocarbon (UHC) emissions to gasoline, but higher hydrocarbons (HC) levels than pure gasoline at higher butanol concentrations. The results also indicated a slight increase in brake specific fuel consumption (BSFC) with the butanol addition. Venugopal et al. [30] studied engine performance with simultaneous injection of butanol and gasoline, as well as blended fuels. On the whole, at all operating conditions, simultaneous injection results in reduced $\mathrm{HC}$ levels and improved or similar performance as compared with B50 (injection of fixed blend). Gu et al. [31] studied combustion in a spark-ignition engine fueled with gasoline-n-butanol blends. It was found that, $\mathrm{HC}$, carbon monoxide $(\mathrm{CO})$ and $\mathrm{NO}_{\mathrm{x}}$ emissions fueled with gasoline and nbutanol blends are lower than those of gasoline. Pure n-butanol increased the $\mathrm{HC}$ and $\mathrm{CO}$ while decreased the $\mathrm{NO}_{\mathrm{x}}$; these tendencies were similar to [28]. Yacoub et al. [32] performed several studies on application of straight-chain alcohols C1-C5 (methanol to pentanol) as fuels blended with gasoline. The study showed that all alcohol-gasoline blends showed reduction in $\mathrm{CO}$ emissions, and total hydrocarbons (THC) emissions were also reduced at optimized operating 
conditions. However, all blends had a higher unburned alcohol emission than gasoline, with the highest emissions coming from those with the highest alcohol content. Aldehyde emissions were higher for all blends with formaldehyde as the main constituent and the $\mathrm{NO}_{\mathrm{x}}$ emissions may increase or decrease depending on different operating conditions. Szwaja and Naber [33] investigated the combustion characteristics of n-butanol in a single cylinder engine and results indicated that the highest peak pressure advanced with the increase of n-butanol ratio due to a faster combustion and the crank angle degree (CAD) of 50\% mass fraction burn (MFB) for $n-$ butanol was approximately $2^{\circ}$ earlier when compared to gasoline. Wallner et al. [34] investigated the combustion, performance, and emissions of pure gasoline, 10\% ethanol (E10) and $10 \%$ butanol (Bu10) blends in a direct-injection (DI) four-cylinder SI engine. Results showed that the burning velocity of the Bu10 was higher than those of both E10 and gasoline. Their further study [35] demonstrated that addition of alcohol to the fuel blend results in a consistent reduction in $\mathrm{NO}_{\mathrm{x}}$ emissions regardless of operating point. Both formaldehyde and acetaldehyde emissions increased with the addition of butanol, whereas formaldehyde did not increase significantly with addition of ethanol. Propene, 1, 3-butadiene, and acetylene emissions, which are required for carbon growth processes leading to benzene, also increased only with the addition of butanol.

Recent studies on $\mathrm{ABE}$ include $\mathrm{ABE}-$ diesel blends combustion in diesel engines (showing simultaneous reductions in $\mathrm{PM}$ and $\mathrm{NO}_{\mathrm{x}}$ emissions) [8] and kinetic modeling of $\mathrm{ABE}$ combustion [36]. Wu et al. [37-42] performed various optical studies on combustion characteristics of $\mathrm{ABE}$ and $\mathrm{ABE}-$ diesel blends in a combustion chamber, and found that $\mathrm{ABE}$ provides tremendous soot and NOx reduction capabilities. It was also found that $\mathrm{ABE}(6: 3: 1)$ showed the highest combustion efficiency, while maintaining phasing close to that of pure diesel. The authors [43-47] have also studied the performance and emissions of ABE-gasoline blends on an SI engine, and found that a small amount of ABE addition could enhance efficiency and reduce emissions. However, to date, combustion characteristics of pure ABE fuels in SI engines have not been investigated. This is the primary motivation for this study. 


\section{Experimental Setup}

\section{Engine Setup}

Most of the experimental setup details have been reproduced from [29], since the same test bench was used for this study. Experiments were conducted using a single cylinder engine with identical cylinder geometry to the V8 engine used in a 2000 Ford Mustang Cobra. The peak power output of the original V8 engine was $239 \mathrm{~kW}$ (329 HP) and $407 \mathrm{Nm}$ (300 lb-ft) of torque resulting in a peak output for the single cylinder engine of slightly less than $30 \mathrm{~kW}$ (40 HP) and $52 \mathrm{Nm}(38 \mathrm{lb}-\mathrm{ft})$ as a result of increased frictional losses. The bottom end is composed of two iron castings produced by Ford. The lower casting houses the crankshaft bearings and the upper casting consists of a single cylinder bore which aligns with cylinder two on the head. The cylinder head is from the left bank of the production V8 engine featuring double overhead camshafts and 4 valves per cylinder with a centrally located spark plug. In order to reduce frictional losses, the rocker arms were removed from cylinders one, three and four. The engine is coupled to a GE type TLC-15 class 4-35-1700 dynamometer capable of delivering up to 14.9 $\mathrm{kW}(20 \mathrm{HP})$ and absorbing up to $26.1 \mathrm{~kW}(35 \mathrm{HP})$ at a maximum rotational speed of $4500 \mathrm{RPM}$. The dynamometer is controlled using a DyneSystems DYN-LOC IV controller and a DyneSystems DTC-1 digital throttle controller. In-cylinder pressure is measured using a Kistler type 6125B pressure transducer and an AVL 3057-AO1 charge amplifier and indexed against a crankshaft position signal from a BEI XH25D shaft encoder.

The engine is controlled through the use of a Megasquirt II V3.0 Engine Control Unit (ECU) which allows the adjustment of fuel through volumetric efficiency tables and adjustment of ignition timing (spark advance) as functions of engine speed (RPM) and engine load (manifold air pressure, (MAP)). The fuel injector used was a Bosch injector \# 0280150558 rated at $440 \mathrm{~cm} 3 / \mathrm{min}$ at a fuel pressure of $3 \mathrm{bar}$.

\section{Exhaust Gas Analyzers}

$\mathrm{NO}_{\mathrm{x}}$ and $\lambda($ and $\Phi)$ measurements were conducted using a Horiba MEXA-720 $\mathrm{NO}_{\mathrm{x}}$ nonsampling type meter in the exhaust manifold of the engine. The measurement range for $\mathrm{NO}_{\mathrm{x}}$ is 0 $3000 \mathrm{ppm}$ with $\pm 30 \mathrm{ppm}$ accuracy for $0-1000 \mathrm{ppm}, \pm 3 \%$ accuracy for $1000-2000 \mathrm{ppm}$, and $\pm 5 \%$ 
accuracy for $2000-3000 \mathrm{ppm}$. The measurement of range for lambda is $0.65-13.7$. To enhance accuracy and ensure reliable data, a LabVIEW code was written to collect and average $\mathrm{NO}_{\mathrm{x}}$ and lambda measurements over a 60 second period at 10 samples per second (600 samples total). Measurements of unburned hydrocarbons and carbon monoxide were made using a Horiba MEXA-554JU sampling type meter. A probe was fabricated to fit in the exhaust manifold of the engine that allowed the sampling tube to transport the exhaust gases to the meter. The measurement range is $0-10,000 \mathrm{ppm}$ for unburned hydrocarbons, $0.00-20.00 \%$ by volume for carbon dioxide, and $0.00-10.00 \%$ by volume for carbon monoxide. Exhaust gas temperature measurements were made using a type- $\mathrm{K}$ thermocouple located in the exhaust manifold. It should be noted that the analyzer used to measure emissions of unburned hydrocarbons uses a non-dispersive infrared analyzer (NDIR). Both NDIR and flame ionization detection (FID) measurements of emissions exhibit low responses to oxygenated hydrocarbons. Engine tests in [35] examined the differences between a Horiba FIA-23A FID analyzer and an MKS 2030 Fourier Transform Infrared (FTIR) analyzer, which can speciate hydrocarbons and more accurately measure oxygenated hydrocarbons. Comparisons between FID and FTIR showed that, for oxygenated fuels, FID consistently underestimated the amount of unburned hydrocarbons although the observed trends were preserved between the two analyzers. However, for the NDIR measurements reported here, using an alcohol fuel does not alter the substance of the results.

\section{Test Fuels}

Ethanol-free Gasoline (Research Octane Number $(\mathrm{RON})=90$ ) was selected as the baseline fuel in this study. The $\mathrm{ABE}$ solution was first prepared at volume ratios of $\mathrm{A}: \mathrm{B}: \mathrm{E}=$ 3:6:1, 6:3:1 and 5:14:1 using analytical grade acetone (99.5\%), butanol (99.5\%) and ethanol (99.8\%). A gravitational test for stability was carried out as samples of the prepared blends were deposited in a test tube at $25{ }^{\circ} \mathrm{C}$ and $1 \mathrm{~atm}$ for 90 days. The blends displayed a clear single phase after the stability test. The n-butanol was supplied by Fisher Scientific while acetone and ethanol meeting USP specs were supplied by Decon Laboratories, Inc. The ABE blend with ABE ratio of 3:6:1 will be referred to as $\mathrm{ABE}(3: 6: 1)$; that with $\mathrm{ABE}$ ratio of $6: 3: 1$ will be referred to as $\operatorname{ABE}(6: 3: 1)$, and so on, in the remainder of the text. Pure gasoline will be referred to as ABE0. The ABE ratio of 3:6:1 is studied because it is the most commonly produced in the fermentation 
product $[16,17]$. The ratio of 6:3:1 is used as it helps in understanding the effect of increasing acetone and decreasing butanol. It has also been found in $[39,45]$ that $\operatorname{ABE}(6: 3: 1)$ showed great potential for improving combustion efficiency. $\operatorname{ABE}(5: 14: 1)$ is investigated as it was studied in [8] and showed promising results in diesel engine combustion. Finally, pure n-butanol is studied for comparison purposes and to further understand the effects of different components.

The properties of individual fuels are listed in Table 2.The difference in the latent heats of vaporization between the fuels is worth noting, as are the different laminar flame speeds (LFS). Note that the latent heat of vaporization of acetone is slightly higher than that of gasoline; however, those of ethanol and butanol are nearly 50-75\% higher than that of gasoline. As far as the LFS is concerned, gasoline has the lowest value among the individual fuels. The LFS plays an important role in the early phase of combustion [33]. The LFS for the components is as follows: Butanol > Ethanol > Acetone > Gasoline [Table 2]. The LFS of ABE(3:6:1) was predicted by Van Geem et al. to be $37 \mathrm{~cm} / \mathrm{s}$ (298 K, Stoichiometric) [36]. This is about $3 \mathrm{~cm} / \mathrm{s}$ higher than gasoline. It is expected that the LFS of the fuels would increase with increasing nbutanol content. However, it is to be noted that a small addition of a component with higher LFS does not show any major effects on the LFS of the blend [50, 51]. Another parameter of importance is the latent heat of vaporization which would cause a charge-cooling effect. Alcohol fuels have been shown to have higher charge-cooling relative to that with gasoline [52]. The LFS strongly depends on temperature. It was shown that the effect of temperature on LFS dominated over the effect of 50\% vol. addition of ethanol to iso-octane [51].

Therefore, it is expected that the combustion phasing of $\mathrm{ABE}$ blends would be determined by the balance between the increase in LFS due to the addition n-butanol, and the decrease in LFS due to the reduction in temperature at ignition by charge-cooling [44]. Finally, acetone with a boiling point of $56{ }^{\circ} \mathrm{C}$ could help the blend's spray collapse significantly, as a small portion of a low boiling point substance within a fuel may be the catalyst to spray collapse, even if the majority constituent of the fuel is not in the region of flash boiling in terms of temperature [53]. Table 3 shows properties of the blends calculated using simple mixing rules. 


\section{Test Conditions}

In this study the engine load was set to 3 bar and 5 bar (BMEP) and the speed at 1200 RPM. The throttle plate was fully opened (Wide Open Throttle). The fuels were first tested under stoichiometric conditions with the same ignition timing as gasoline's MBT $\left(18^{\circ}\right.$ Before Top Dead Center (BTDC) at 3 bar and $24^{\circ}$ BTDC at 5 bar BMEP, the default values for gasoline on this engine), to perform an analysis of ABE use in SI engines without any modifications. Next, each fuel was tested at its own MBT (Table 5) and an air/fuel ratio sweep was performed. It should be noted that the engine started up immediately using all fuels except n-butanol, for which the engine had to be warmed up beforehand. This is likely due to the enhanced volatility of $\mathrm{ABE}$ fuels due to the presence of acetone. Measurements of brake torque, lambda, and NOx were averaged of a 60-second period while UHC, CO and exhaust gas temperature (EGT) measurements were recorded directly from the emissions analyzer. In addition, in-cylinder pressure traces were taken for all fuels to examine the differences in peak cylinder pressure. The experiments were performed 3 times and these datasets were then averaged. The tests were performed in a temperature-controlled laboratory; so the effects of humidity were assumed to be negligible. The intake air pressure was controlled using an electronic regulator which provides precise control (Accuracy: +/- $0.1 \mathrm{kPa}$ ). Furthermore, the engine was allowed to run at every operating condition for an extended period of time to ensure steady state measurements. The conditions used in this test are summarized in Table 4.

\section{Results and Discussion}

The results under stoichiometric conditions and gasoline MBT are first presented and discussed in detail, after which, results over the range of equivalence ratios tested at each fuel's MBT are presented for completeness and briefly discussed. Although the tests were performed at both 3 and 5 bar BMEP under the fuels' MBTs, only the 3 bar results are shown for brevity's sake. The results under 5 bar BMEP showed similar trends. The in-cylinder pressure traces are first presented to compare differences in peak cylinder pressure between the fuels. Next, emissions measurements are presented starting with UHC. UHC emissions are presented first since they provide insight into how well the fuel mixes with the air and is consumed during the combustion process. Emissions of carbon monoxide are then shown to estimate the completion Page 9 of 38 
of combustion, followed by $\mathrm{NO}_{\mathrm{x}}$ emissions to analyze the effect of ABE's lower energy content on $\mathrm{NO}_{\mathrm{x}}$ production. The error bars in the figures show the standard error.

\section{In-Cylinder Pressure Traces}

Figure 2(a) shows the pressure traces of all tested fuels at 3 bar BMEP and gasoline MBT at $\Phi=1$. The traces shown are the mean traces of several 25 consecutive engine cycle samples recorded over a 60 second period. The peak cylinder pressures of all ABE fuels except $\mathrm{ABE}(6: 3: 1)$ are higher compared to that of gasoline. $\mathrm{ABE}(6: 3: 1)$ shows the most retarded phasing due to it having the lowest LFS. $\operatorname{ABE}(3: 6: 1)$ shows a slightly advanced peak pressure because its' higher flame speed which causes the combustion to initiate faster and approach completion, leading to a higher combustion peak and advanced CAD position with respect to gasoline. Figure 2(b) shows the pressure traces of all tested fuels at 3 bar BMEP and each fuel's own MBT (shown in Table 5), under stoichiometric conditions. It appears that at their MBTs, $\operatorname{ABE}(3: 6: 1), \operatorname{ABE}(5: 14: 1)$ and n-butanol show similar combustion phasing, whereas, $\mathrm{ABE}(6: 3: 1)$ and gasoline behave similarly. However, $\operatorname{ABE}(6: 3: 1)$ has a marginally retarded phasing.

\section{Mass Fraction Burnt (MFB) Profiles}

Normalized MFB plots, which can express heat release from combustion, were determined from each of the pressure traces and illustrated in Fig. 3. In this analysis the heat transfer to walls and fuel flow into crevices were neglected. Therefore, the apparent heat release rate was calculated from the pressure trace using the first law of thermodynamics as expressed in Eq.(1).

$$
\frac{d Q_{n}}{d t}=\frac{\gamma}{\gamma-1} p \frac{d V}{d t}+\frac{1}{\gamma-1} V \frac{d p}{d t}
$$

where, $\gamma$ is the specific heat ratio, $\mathrm{p}$ is the in-cylinder pressure, $\mathrm{V}$ is the cylinder volume, and $Q_{n}$ is apparent heat release.

From Fig. 3, quantities such as 10\% MFB, 50\% MFB and 90\% MFB can be determined. These values correspond to $0.1,0.5$ and 0.9 of normalized MFB, respectively. The ignition delay 
shown in Fig. 4 (a) is calculated as the difference between the spark timing and 0.1 MFB timing; combustion duration presented in Fig. 4 (c) is calculated as a difference between 0.9 MFB and 0.1 MFB. They are expressed in degrees of crankshaft angle.

Fig. 4 (a) shows the ignition delay for the different fuels at both 3 and 5 bar BMEP, at gasoline MBT at $\Phi=1$. During this period of early combustion, the combustion rate is impacted by the laminar flame speed of the fuel-air mixture. At later times which are in the fully developed bulk burn, the combustion is dominated by turbulent flame propagation [33]. $\operatorname{ABE}(3: 6: 1), \operatorname{ABE}(5: 14: 1)$ and n-butanol show similar, relatively shorter ignition delays, followed by gasoline, and $\mathrm{ABE}(6: 3: 1)$ having the longest ignition delay. This trend is in accordance with the LFS of the fuels, and this effect is further pronounced at 5 bar BMEP. Fig. 4 (b) shows the CA50 location for the different fuels under the same conditions. The CA50 trends are similar to those seen for ignition delay. Under 5 bar, the difference in CA50 between $\operatorname{ABE} 0$ and $\operatorname{ABE}(3: 6: 1), \operatorname{ABE}(5: 14: 1)$ is about $1.2^{\circ}$ (advanced), and that between $\mathrm{ABE} 0$ and $\mathrm{ABE}(6: 3: 1)$ is about $1^{\circ}$ (retarded). The 50\% MFB represents the center of combustion and it has been shown that the engine torque strongly depends on the location of 50\% MFB. From Fig. 4(c), we can see that the combustion duration trends at 3 bar BMEP are similar to those observed for CA50. At 5 bar BMEP, it appears that all ABE fuels show slightly longer combustion duration than that of pure gasoline.

Fig. 5 shows the ignition delay (top), CA50 (middle) and combustion duration for the different fuels at 3 bar BMEP, at the fuels' MBT at varying equivalence ratios. It is apparent that the fuels behave most similarly near stoichiometric and richer conditions. At leaner equivalence ratios, the combustion behavior is more widely separated. A shorter ignition delay is observed at richer equivalence ratios. This is due to the fact that flame development is slower at leaner equivalence ratios [49]. It can be seen that throughout the equivalence ratio range tested, combustion phasing is consistent with the amount of butanol in the fuel. As butanol content increases, phasing gets advanced. $\operatorname{ABE}(3: 6: 1), \operatorname{ABE}(5: 14: 1)$ and n-butanol behave quite similarly, whereas gasoline and $\operatorname{ABE}(6: 3: 1)$ have similar phasing. Fuels with higher n-butanol show shorter ignition delays and combustion durations due to higher LFS. ABE (6:3:1) behaves similar to ABE0 for the most part, likely because these two fuels would have almost similar LFSs. As such, the trends observed are similar to those in [27, 28, 32, 33], where the addition of Page 11 of 38 
butanol advanced combustion phasing. In summary, $\operatorname{ABE}(6: 3: 1)$ does not cause an appreciable change in phasing, however, $\operatorname{ABE}(3: 6: 1)$ and $\mathrm{ABE}(5: 14: 1)$ advance combustion phasing.

\section{Brake Specific Fuel Consumption \& Efficiency}

Figure 6 shows the brake specific fuel consumption (BSFC) of different fuels. The brake specific fuel consumption (BSFC) represents the fuel consumption as a function of engine power.

All test blends have higher BSFC than gasoline because of their lower LHV (seen in Table 3). ABE(6:3:1) has the lowest LHV among the fuels, so its BSFC is the highest at the same output torque. At $\Phi=1$, the BSFC of the blends was roughly $10-30 \%$ higher than that of ABE0.

The fuel energy input changes with the fuel properties, mainly based on the ratio of lower heating value to stoichiometric air demand. To ensure an unbiased comparison and to better evaluate the fuel economy of alternative fuels, the Gasoline Equivalent BSFC is used in this study, which is defined as follows:

$$
\text { Gasoline Equivalent BSFC }=B S F C_{\text {blends }} X \frac{L H V_{\text {blends }}}{L H V_{\text {gasoline }}}
$$

Fig. 7 (a) shows the Gasoline Equivalent BSFC of the fuels. The differences in Gasoline Equivalent BSFC among all test fuels are much less compared to those in BSFC. The relatively lower Gasoline Equivalent BSFC of $\operatorname{ABE}(6: 3: 1)$ indicates a higher BTE (Fig. 7 (b)). ABE(6:3:1) shows relatively higher efficiency than all other fuels at stoichiometric and richer air/fuel ratios, whereas butanol shows highest efficiency at leaner air/fuel ratios. The other fuels show slightly higher efficiency relative to that of gasoline. For instance, at $\Phi=1$, the BTE of $\mathrm{ABE}(6: 3: 1)$ is $1.6 \%$ higher than that of ABE0, whereas n-butanol shows an increase of $1 \%$ relative to ABE0. The relatively lower efficiency of the blends with higher butanol content is likely due to their retarded spark timing and incomplete combustion as seen by a spike in $\mathrm{HC}$ and $\mathrm{CO}$ emissions (shown later).

The higher thermal efficiency of $\operatorname{ABE}(6: 3: 1)$ can be attributed to the fact that blends with low carbon numbers contain more oxygen than those with high carbon numbers. As a result, 
combustion is improved, thereby enhancing thermal efficiency. Secondly, from Fig. 2(b), it can be seen that $\mathrm{ABE}(6: 3: 1)$ 's compression work is quite reduced compared to the other fuels. From Fig. 5, it can be observed that $\operatorname{ABE}(6: 3: 1)$ shows relatively similar CA50 as that of gasoline, however, it has a longer combustion duration. This reduced compression work increases the net work output, and the slower rate of combustion leads to comparatively lower heat losses, and better post-flame $\mathrm{HC}$ and $\mathrm{CO}$ oxidation, which ultimately leads to a higher thermal efficiency. Acetone's higher volatility is likely to make it easier to burn thus approaching complete combustion, as indicated by $\mathrm{ABE}(6: 3: 1)$ 's reduced $\mathrm{HC}$ and $\mathrm{CO}$ emissions (shown later). In Direct Injection (DI) engines, fuel is vaporized in the compression stroke when latent heat of vaporization is high. Given that fuel absorbs heat from the cylinder during vaporization, the airfuel mixture is compressed more easily, thus improving thermal efficiency [25]. This indicates the potential for consumption reductions in DI spark ignition engines. The higher acetone content would also enhance spray collapse and mixing and make the fuel much more volatile. Therefore, acetone addition could improve combustion quality significantly. In summary, the typically produced fermentation product, i.e., $\operatorname{ABE}(3: 6: 1)$ may not be ideal for engine combustion. In terms of efficiency, fermentation products with higher acetone content, such as $\operatorname{ABE}(6: 3: 1)$ would be much better suited as alternative fuels for SI engines.

\section{Exhaust Gas Temperature}

EGT provides insight into the combustion process by measuring the temperature of the burned gases directly after they exit the engine. With ignition timing fixed, the differences in EGT should be proportional to the combustion temperature of the fuels. Fig. 8 shows the EGT of different at $\Phi=1$. It can be seen that there is no real change in the exhaust temperature. Even though the blends have a higher latent heat of vaporization and a lower heating value than gasoline, their pressure traces and combustion phasing were relatively similar, and hence the EGTs are not affected significantly.

\section{Emission Behavior}

All reported emissions are raw emissions without the use of a catalytic converter. UHC emissions provide direct insight into the combustion process by measuring how much fuel is left over after the combustion of the fuel-air mixture. Engine-out THC emissions are primarily a Page 13 of 38 
result of engine configuration, fuel structure, oxygen availability, and residence time. It might be hypothesized that the addition of an alcohol such as ethanol or butanol to gasoline would improve THC oxidation due to the higher oxygen content in the cylinder and exhaust. However, note that the engine is operated at the stoichiometric air fuel ratio for each specific fuel blend and thus, excess oxygen is not available [34].

Figures 9(a) and 9(b) show the UHC emissions at gasoline MBT $(\Phi=1)$ and fuels' MBT, respectively. The $\mathrm{HC}$ emissions are reduced with the use of $\operatorname{ABE}(6: 3: 1)$, which shows the lowest HC emissions. This is due to higher oxygen content, higher volatility and better postflame oxidation of the fuel, likely due to the impact of acetone. However, with higher butanol content, the $\mathrm{HC}$ emissions rise steeply, as shown by $\operatorname{ABE}(5: 14: 1)$ and n-butanol. From Fig. 9(b), it is seen that similar behavior is observed at all equivalence ratios under the fuels' MBT. The increase of $\mathrm{HC}$ with increasing butanol addition is consistent with the literature [26, 28]. This is due to butanol's high latent heat of vaporization, which could reduce the combustion temperature and lead to unburnt fuel.

$\mathrm{CO}$ production is primarily controlled by the air/fuel ratio in the cylinder. Mixtures richer than stoichiometric produce high levels of $\mathrm{CO}$ and are sensitive to small changes in air/fuel ratio. Mixtures at stoichiometric and leaner produce little $\mathrm{CO}$ emissions and are relatively insensitive to air/fuel ratio changes [34]. Figures 10(a) and 10(b) show the CO emissions at gasoline MBT $(\Phi=1)$ and fuels' MBT, respectively. From Fig. 10(a), it is observed that $\mathrm{CO}$ emissions for the alcohol fuels are consistently higher than that for gasoline. $\mathrm{ABE}(3: 6: 1)$ has the highest $\mathrm{CO}$ emissions, while that for $\operatorname{ABE}(6: 3: 1)$ is very close to that of $\mathrm{ABE} 0$. This is also reflected in the increased BTE exhibited by $\operatorname{ABE}(6: 3: 1)$ and the reduced BTE of $\operatorname{ABE}(3: 6: 1)$. $A B E(3: 6: 1), \operatorname{ABE}(5: 14: 1)$ and n-butanol show relatively similar $C O$ emissions. From Fig. 10(b), it is seen that the CO emissions are slightly improved at the fuels' MBTs; however, increasing butanol content results in increasing $\mathrm{CO}$ emissions at $\Phi=1$. Decreases in both $\mathrm{CO}$ post-flame oxidation and engine power output are responsible for this.

It appears that $\mathrm{ABE}(6: 3: 1)$ can improve both power output and emissions behavior. Also, $\mathrm{ABE}(6: 3: 1)$ and gasoline show roughly similar emissions behavior. This makes sense as fuels with similar CA50 for a given start of ignition (SOI) are known to show similar emissions Page 14 of 38 
behavior [54]. The effect of acetone is to keep $\mathrm{ABE}(6: 3: 1)$ 's phasing close to that of gasoline, while improving efficiency and reducing emissions.

Figures 11(a) and 11(b) show the NOx emissions at gasoline MBT $(\Phi=1)$ and fuels' MBT, respectively. From Fig. 11(a), no major changes are seen in $\mathrm{NO}_{\mathrm{x}}$ emissions between gasoline, $\mathrm{ABE}(6: 3: 1)$ and $\mathrm{ABE}(3: 6: 1)$. With increasing butanol content, $\mathrm{NO}_{\mathrm{x}}$ decreases slightly for $\operatorname{ABE}(5: 14: 1)$ and n-butanol. This agrees with the results in $[26,28,31]$ where no major changes in $\mathrm{NO}_{\mathrm{x}}$ emissions were observed for blends of gasoline and n-butanol (i.e., relatively lower butanol content). Similar behavior is observed across the equivalence ratio range tested, as shown in Fig. 11(b), where n-butanol consistently shows lowest NOx emissions. Combustion approaches close to completion under stoichiometric conditions, which leads to higher peak combustion temperatures, and hence the highest $\mathrm{NO}_{\mathrm{x}}$ emissions are seen at stoichiometric conditions with a decrease as the equivalence ratio gets relatively richer or leaner. The lower NOx measured with increasing butanol is in accordance with higher vaporization heat, typical of oxygenated compounds, giving lower air/fuel mixture temperature at intake and, as a consequence, lower peak temperatures in the combustion chamber. The mixture temperature at intake valve closing, measured during experiments, is progressively lower with alcohol increasing in blends [28].

\section{Conclusions}

Blends of Acetone-Butanol-Ethanol (ABE) (6:3:1, 3:6:1 and 5:14:1 vol. \% ratio), were combusted in a PFI SI engine with ethanol-free gasoline and pure n-butanol as baselines for comparison, and the combustion performance and emission behavior were analyzed. The fuels were combusted at 1200 RPM, and 3 bar and 5 bar BMEP (medium load) and measurements such as brake torque and emissions were made along with in-cylinder pressure data. Each fuel was tested across a range of equivalence ratios, from lean to rich. The blends' MBT timings were also found at the tested conditions.

In-cylinder pressure data showed that under gasoline MBT, the peak pressure of the ABE blends was slightly higher than that of gasoline, while $\operatorname{ABE}(3: 6: 1)$ also showed an advanced peak relative to gasoline. Under their MBT timings, $\mathrm{ABE}(3: 6: 1), \mathrm{ABE}(5: 14: 1)$ and n-butanol 
showed similar phasing, whereas $\mathrm{ABE}(6: 3: 1)$ and gasoline behaved similarly. Increasing $\mathrm{n}$ butanol showed advanced combustion phasing (CA50) which is attributed to the increase in laminar flame speed due to butanol's higher flame speed. $\operatorname{ABE}(6: 3: 1)$, however, displayed combustion phasing similar to that of ABE0, although slightly retarded. Similar trends were observed at all equivalence ratios.

The BSFC increased steadily with the ABE blends, due to the lower energy content of the blends and thus more fuel was required to match the power output of gasoline. The BTE of $\mathrm{ABE}(6: 3: 1)$ was higher than that of $\mathrm{ABE} 0$, whereas other fuels showed similar or slightly higher efficiency relative to ABE0.

Emission data showed that increasing n-butanol showed increased HC emissions and increased $\mathrm{CO}$ emissions, due to incomplete combustion. On the other hand, $\operatorname{ABE}(6: 3: 1)$ showed reduced $\mathrm{HC}$ emissions. $\mathrm{CO}$ for $\mathrm{ABE}(6: 3: 1)$ was roughly the same as that of $\mathrm{ABE} 0$. With respect to $\mathrm{NO}_{x}$, no major changes were observed between gasoline and $\operatorname{ABE}(6: 3: 1), \operatorname{ABE}(3: 6: 1)$, which was supported by the minor variations in exhaust gas temperature.

Acetone addition could improve combustion quality significantly. In summary, the typically produced fermentation product, i.e., $\operatorname{ABE}(3: 6: 1)$ may not be ideal for engine combustion in terms of thermal efficiency. Fermentation products with higher acetone content, such as $\mathrm{ABE}(6: 3: 1)$ would be much better suited as alternative fuels for SI engines. This study further affirms the potential of $\mathrm{ABE}$ to be used as an alternative fuel in SI engines. Future work will involve testing of $\mathrm{ABE}$ fuels containing water.

\section{Acknowledgments}

This material is based upon work supported by the National Science Foundation under Grant No. CBET-1236786. Any opinions, findings, and conclusions or recommendations expressed in this publication are those of the author(s) and do not necessarily reflect the views of the National Science Foundation.

\section{Definitions/Abbreviations}

ABE Acetone-Butanol-Ethanol

Page 16 of 38 


$\begin{array}{ll}\text { ASOI } & \text { After Start of Ignition } \\ \text { ATDC } & \text { After Top Dead Center } \\ \text { BMEP } & \text { Brake Mean Effective Pressure } \\ \text { BSFC } & \text { Brake Specific Fuel Consumption } \\ \text { BTDC } & \text { Before Top Dead Center } \\ \text { BTE } & \text { Brake Thermal Efficiency } \\ \text { CAD } & \text { Crank Angle Degree } \\ \text { COV } & \text { Co-efficient of Variation } \\ \text { CO } & \text { Carbon Monoxide } \\ \text { DI } & \text { Direct Injection } \\ \text { ECU } & \text { Engine Control Unit } \\ \text { EGT } & \text { Exhaust Gas Temperature } \\ \text { ETE } & \text { Engine Thermal Efficiency } \\ \text { FID } & \text { Flame Ionization Detection } \\ \text { GE BSFC } & \text { Gasoline Equivalent BSFC } \\ \text { HC } & \text { Hydro-Carbons } \\ \text { HoV } & \text { Heat of Vaporization } \\ \text { ICE } & \text { Internal Combustion Engine } \\ \text { IMEP } & \text { Indicated Mean Effective Pressure } \\ \text { LFS } & \text { Laminar Flame Speed } \\ \text { LHV } & \text { Lower Heating Value } \\ \text { MAP } & \text { Manifold Air Pressure } \\ \text { MFB } & \text { Mass Fraction Burnt } \\ \text { NDIR } & \text { Non-Dispersive Infrared } \\ \text { NO } & \text { Nitrogen Oxides } \\ \text { PFI } & \text { Port-Fuel Injection } \\ \text { RON } & \text { Research Octane Number } \\ \text { RPM } & \text { Revolutions per minute } \\ \text { SI } & \text { Spark Ignition } \\ \text { SOI } & \text { Start of Ignition } \\ & \end{array}$




$\begin{array}{ll}\text { THC } & \text { Total Hydro-Carbons } \\ \text { UHC } & \text { Unburned Hydro-Carbons } \\ \Phi & \text { Equivalence Ratio } \\ \lambda & \text { Lambda }(=1 / \Phi)\end{array}$

\section{References}

1. Song, K., Nag, P., Litzinger, T.A., Haworth, D.C., "Effects of oxygenated additives on aromatic species in fuel-rich, premixed ethane combustion: a modeling study," Combustion and Flame 135(3):341-349, 2008, doi: 10.1016/S0010-2180(03)00180-9.

2. Kumar, S., Cho, J.H., Park, J., Moon, I., "Advances in Diesel-Alcohol Blends and their Effects on the Performance and Emissions of Diesel Engines," Renewable and Sustainable Energy Reviews 22:46-72, 2013, doi: 10.1016/j.rser.2013.01.017.

3. Kumar, M., Goyal, Y., Sarkar, A., Gayen, K., "Comparative economic assessment of ABE fermentation based on cellulosic and non-cellulosic feedstocks," Applied Energy 93:193-204, 2012, doi: 10.1016/j.apenergy.2011.12.079.

4. Rajasekar, E., Murugesan, A., Subramanian, R., Nedunchezhian, N., "Review of NOx reduction technologies in CI engines fuelled with oxygenated biomass fuels," Renewable and Sustainable Energy Reviews 14(7):2113-2121, 2010, doi: 10.1016/j.rser.2010.03.005.

5. Qureshi, N., Ezeji, T.C., "Butanol, 'a Superior Biofuel' Production from Agricultural Residues (Renewable Biomass): Recent Progress in Technology," Biofuels, Bioproducts and Biorefining 2(4):319-330, 2008, doi: 10.1002/bbb.85.

6. He, B.-Q., Liu, M.-B., Yuan, J., Zhao, H., “Combustion and emission's characteristics of a HCCI engine fuelled with n-butanol-gasoline blends," Fuel 108:668-674, 2013, doi: 10.1016/j.fuel.2013.02.026.

7. Jones, D.T., Woods, D.R., "Acetone-Butanol Fermentation revisited," Microbiological Reviews 50(4):484-524, 1986.

8. Chang, Y.-C., Lee, W.-J., Lin, S.-L., Wang, L.-C., "Green Energy: Water Containing Acetone-Butanol-Ethanol Diesel Blends Fueled in Diesel Engines," Applied Energy 109:182191, 2013, doi:10.1016/j.apenergy.2013.03.086. 
9. Dusséaux, S., Croux, C., Soucaille, P., Meynial-Salles, I., "Metabolic Engineering of Clostridium Acetobutylicum ATCC 824 for Isopropanol-Butanol-Ethanol Fermentation”, Metabolic Engineering 18:1-8, 2013, doi: 10.1016/j.ymben.2013.03.003.

10. Jang, Y.-S., Malaviya, A., Cho, C., Lee, J., et al., "Butanol Production from Renewable Biomass by Clostridia," Bioresource Technology 123:653-663, 2012, doi:10.1016/j.biortech.2012.07.104.

11. Kraemer, K., Harwardt, A., Bronneberg, R., Marquardt, W., "Separation of Butanol from Acetone-Butanol_Ethanol Fermentation by a Hybrid Extraction-Distillation Process," Computers and Chemical Engineering 35(5):949-963, 2012, doi:10.1016/j.compchemeng.2011.01.028.

12. Qureshi, N., Hughes, S., Maddox, I.S., Cotta, M.A., "Energy-Efficient Recovery of Butanol from Model Solutions and Fermentation Broth by Adsorption," Bioprocess and Biosystems Engineering 27(4):215-222, 2005, doi:10.1007/s00449-005-0402-8.

13. Crabbe, E., Nolasco-Hipolito, C., Kobayashi, G., Sonomoto, K., et al., "Biodiesel Production from Crude Palm Oil and Evaluation of Butanol Extraction and Fuel Properties," Process Biochemistry 37(1):65-71, 2001, doi:10.1016/S0032-9592(01)00178-9.

14. Qureshi, N., "Application of Continuous Substrate Feeding to the ABE Fermentation: Relief of Product Inhibition Using Extraction, Perstraction, Stripping, and Pervaporation," Biotechnology Progress 8(5):382-390, 1992, doi:10.1021/bp00017a002.

15. Afschar, A.S., Biebl, H., Schaller, K., Schugerl, K., "Production of Acetone and Butanol by Clostridium Acetobutylicum in a Continuous Culture with Cell Recycle," Applied Microbiology and Biotechnology 22(6):394-398, 1985, doi:10.1007/BF00257026.

16. Liu, F., Liu, L., Feng, X., "Separation of Acetone-Butanol-Ethanol (ABE) From Dilute Aqueous Solutions by Pervaporation," Separation and Purification Technology 42(3):273282, 2005, doi:10.1016/j.seppur.2004.08.005.

17. García, V., Päkkilä, J., Ojamo, H., Muurinen, E., et al., "Challenges in Biobutanol Production: How to improve Efficiency," Renewable and Sustainable Energy Reviews 15(2):964-980, 2011, doi:10.1016/j.rser.2010.11.008.

18. Li, X., Shi, Z. P., Li, Z. G., "Increasing butanol/acetone ratio and solvent productivity in $\mathrm{ABE}$ fermentation by consecutively feeding butyrate to weaken metabolic strength of butyrate loop," Bioprocess Biosyst Eng. 2014; 37: 1609-16.

Page 19 of 38 
19. Sabra, W., Groeger, C., Sharma, P. N., Zeng, A. P., "Improved n-butanol production by a non-acetone producing Clostridium pasteurianum DSMZ 525 in mixed substrate fermentation," Appl Microbiol Biotechnol. 2014; 98: 4267-76.

20. Zheng, Z., Li, C., Liu, H., Zhang, Y., et al., "Experimental study on diesel conventional and low temperature combustion by fueling four isomers of butanol," Fuel 141:109-119, 2015, doi:10.1016/j.fuel.2014.10.053.

21. Zheng, Z., Yue, L., Liu, H., Zhu, Y., et al., "Effect of two-stage injection on combustion and emissions under high EGR rate on a diesel engine by fueling blends of diesel/gasoline, diesel/n-butanol, diesel/gasoline/n-butanol and pure diesel," Energy Conversion and Management 90:1-11, 2015, doi:10.1016/j.enconman.2014.11.011.

22. Liu, H., Wang, X., Zheng, Z., Gu, J., et al., "Experimental and simulation investigation of the combustion characteristics and emissions using n-butanol/biodiesel dual-fuel injection on a diesel engine," Energy 74: 741-752, 2014, doi:10.1016/j.energy.2014.07.041.

23. Liu, H., Huo, M., Liu, Y., Wang, X., et al, “Time-resolved spray, flame, soot quantitative measurement fueling n-butanol and soybean biodiesel in a constant volume chamber under various ambient temperatures," Fuel 133: 317-325, 2014, doi:10.1016/j.fuel.2014.05.038.

24. Liu, H., Li, S., Zheng, Z., Xu, J., et al., "Effects of n-butanol, 2-butanol, and methyl octynoate addition to diesel fuel on combustion and emissions over a wide range of exhaust gas recirculation (EGR) rates," Applied Energy 112: 246-256, 2013, doi:10.1016/j.apenergy.2013.06.023.

25. Masum, B. M., Kalam, M. A., Masjuki, H. H., Palash, S. M. et al., "Performance and emission analysis of a multicylinder gasoline engine operating at different alcohol-gasoline blends." RSC Adv., 2014, 4, 27898, doi: 10.10 39/c4ra0 4580g.

26. Costagliola, M. A., De Simio, L., Iannaccone, S., Prati, M. V., "Combustion efficiency and engine out emissions of a SI engine fueled with alcohol/gasoline blends," Applied Energy 111 (2013), pp. 1162-1171, http://dx.doi.org/10.1016/j.apenergy.2012.09.042.

27. Williams, J., Goodfellow, C., Lance, D., Ota, A. et al., "Impact of Butanol and Other BioComponents on the Thermal Efficiency of Prototype and Conventional Engines," SAE Technical Paper 2009-01-1908, 2009, doi:10.4271/2009-01-1908. 
28. Dernotte, J., Mounaim-Rousselle, C., Halter, F., Seers, P., Evaluation of butanol-gasoline blends in a port fuel-injection, spark-ignition engine," Oil Gas Sci Technol - Rev IFP 65(2):345-51, 2010, doi:10.2516/ogst/2009034.

29. Wigg, B., Coverdill, R., Lee, C., and Kyritsis, D., "Emissions Characteristics of Neat Butanol Fuel Using a Port Fuel-Injected, Spark-Ignition Engine," SAE Technical Paper 2011-010902, 2011, doi:10.4271/2011-01-0902.

30. Venugopal, T., Ramesh, A., "Performance, combustion and emission characteristics of a spark-ignition engine with simultaneous injection of $\mathrm{n}$-butanol and gasoline in comparison to blended butanol and gasoline," Int. J. Energy Res. 2014; 38:1060-1074, doi: 10.1002/er.3113.

31. Gu, X., Huang, Z., Cai, J, Gong, J., et al., "Emission characteristics of a spark-ignition engine fuelled with gasoline-n-butanol blends in combination with EGR," Fuel 93:611-7, 2012, doi:10.1016/j.fuel.2011.11.040.

32. Yacoub, Y., Bara, R., Gautam, M., "The performance and emission characteristics of C1-C5 alcohol-gasoline blends with matched oxygen content in a single cylinder spark ignition engine," Proceedings of the Institution of Mechanical Engineers, Part A: Journal of Power and Energy 212(5):363-79, 1998, doi:10.1243/0957650981536934.

33. Szwaja, S., Naber, J.D., "Combustion of n-butanol in a spark-ignition IC engine”, Fuel 89:1573-82, 2010, doi:10.1016/j.fuel.2009.08.043.

34. Wallner, T., Miers, S. A., McConnell, S., "A Comparison of Ethanol and Butanol as Oxygenates using a Direct-Injection, Spark-Ignition Engine," J. Eng. Gas Turbines Power 131(3), 2009, doi:10.1115/1.3043810.

35. Wallner, T. and Frazee, R., "Study of Regulated and Non-Regulated Emissions from Combustion of Gasoline, Alcohol Fuels and their Blends in a DI-SI Engine," SAE Technical Paper 2010-01-1571, 2010, doi:10.4271/2010-01-1571.

36. Van Geem, K.M., Cuoci, A., Frassoldati, A., Pyl, S.P., et al., “An Experimental and Kinetic Modeling Study of Pyrolysis and Combustion of Acetone-Butanol-Ethanol (ABE) Mixtures," Combust. Sci. Technol. 184:942-955, doi:10.1080/00102202.2012.663987.

37. Wu, H., Nithyanandan, K., Li, B., Huo, M., Zhou, N., Lee, C., Zhang, C. "Investigation on spray and soot lift-off length of ABE-diesel blend in a constant volume chamber with diesel engine conditions," Proc. ASME. 46162; Volume 1: Large Bore Engines; Fuels; Advanced Page 21 of 38 
Combustion; Emissions Control Systems, V001T02A011.October 19, 2014, ICEF2014-5645, doi: 10.1115/ICEF2014-5645.

38. Wu, H., Nithyanandan, K., Lee, T. H., Lee, C. F., Zhang, C., "Spray and Combustion Characteristics of Neat Acetone-Butanol-Ethanol, n-Butanol, and Diesel in a Constant Volume Chamber", Energy \& Fuels 201428 (10), 6380-6391, DOI:10.1021/ef5013819.

39. Wu, H., Nithyanandan, K., Zhou, N., Lee, T. H., Lee, C. F., Zhang, C., "Impacts of acetone on the spray combustion of Acetone-Butanol-Ethanol (ABE)-Diesel blends under low ambient temperature", Fuel, Volume 142, 15 February 2015, Pages 109-116, ISSN 00162361, http://dx.doi.org/10.1016/j.fuel.2014.10.009.

40. Zhou, N., Huo, M., Wu, H., Nithyanandan K., Lee, C. F., Wang, Q., "Low temperature spray combustion of acetone-butanol-ethanol (ABE) and diesel blends," Applied Energy, Volume 117, 2014, pp:104-115, ISSN 0306-2619, http://dx.doi.org/10.1016/j.apenergy.2013.11.035.

41. Wu, H., Huo, M., Zhou, N., Nithyanandan, K. et al., "An Experimental Investigation of the Combustion Characteristics of Acetone-Butanol-Ethanol-Diesel Blends with Different ABE Component Ratios in a Constant Volume Chamber," SAE Technical Paper 2014-01-1452, 2014, doi:10.4271/2014-01-1452.

42. Lin, Y., Wu, H., Nithyanandan, K., Lee, T. H., Lee, C. F., Zhang, C., "Investigation of High Percentage Acetone-Butanol-Ethanol (ABE) Blended With Diesel in a Constant Volume Chamber," Proc. ASME. 46162; Volume 1: Large Bore Engines; Fuels; Advanced Combustion; Emissions Control Systems, V001T02A012.October 19, 2014, ICEF2014-5649, doi: 10.1115/ICEF2014-5649

43. Nithyanandan, K., Wu, H., Huo, M., and Lee, C., "A Preliminary Investigation of the Performance and Emissions of a Port-Fuel Injected SI Engine Fueled with Acetone-ButanolEthanol (ABE) and Gasoline," SAE Technical Paper 2014-01-1459, 2014, doi:10.4271/201401-1459.

44. Nithyanandan, K., Wu, H., Zhang, J., and Lee, C. F., "Performance and Emissions of Acetone-Butanol-Ethanol (ABE) and Gasoline Blends in a Port Fuel Injected Spark Ignition Engine", Proc. ASME. 46162; Volume 1: Large Bore Engines; Fuels; Advanced Combustion; Emissions Control Systems, V001T02A010.October 19, 2014, ICEF2014-5644, doi: 10.1115/ICEF2014-5644. 
45. Nithyanandan, K., Zhang, J., Li, Y., Wu, H., Lee, C., F., "Investigating the Impact of Acetone on the Performance and Emissions of Acetone-Butanol-Ethanol (ABE) and Gasoline Blends in an SI Engine," SAE Technical Paper 2015-01-0909, 2015. (accepted, but not published yet)

46. Zhang, J., Nithyanandan, K., Li, Y., Lee, C., F., Huang, Z., "Comparative Study of HighAlcohol-Content Gasoline Blends in an SI Engine," SAE Technical Paper 2015-01-0891, 2015. (accepted, but not published yet)

47. Li, Y., Nithyanandan, K., Zhang, J., Lee, C., F., Liao, S., "Combustion and Emissions Performance of a Spark Ignition Engine Fueled with Water Containing Acetone-ButanolEthanol and Gasoline Blends," SAE Technical Paper 2015-01-0908, 2015. (accepted, but not published yet)

48. Zuehl, J. R., "Fuel Effects on Homogeneous Charge Compression Ignition Combustion," M.S. thesis. Department of Mechanical Engineering, University of Wisconsin-Madison, Madison, 2009.

49. Andrae, J.C.G., "Development of a detailed kinetic model for gasoline surrogate fuels," Fuel 87:2013-2022, 2008, doi:10.1016/j.fuel.2007.09.010.

50. Dirrenberger, P., Glaude, P. A., Bounaceur, R., Le Gall, H., et al., "Laminar burning velocity of gasolines with addition of ethanol," Fuel 115:162-169, 2014, doi: http://dx.doi.org/10.1016/j.fuel.2013.07.015.

51. van Lipzig, J. P. J., Nilsson, E. J. K., de Goey, L. P. H., Konnov, A. A., "Laminar burning velocities of n-heptane, iso-octane, ethanol and their binary and tertiary mixtures", Fuel 90:2773-2781, 2011, doi: http://dx.doi.org/10.1016/j.fuel.2011.04.029

52. Aleiferis, P. G., Serras-Pereira, J., Richardson, D., "Characterization of flame development with ethanol, butanol, iso-octane, gasoline and methane in a direct-injection spark-ignition engine,“ Fuel 109:256-278, 2011, doi: http://dx.doi.org/10.1016/j.fuel.2012.12.088.

53. Aleiferis, P., Malcolm, J., Todd, A., Cairns, A. et al., "An Optical Study of Spray Development and Combustion of Ethanol, Iso-Octane and Gasoline Blends in a DISI Engine," SAE Technical Paper 2008-01-0073, 2008, doi:10.4271/2008-01-0073.

54. Kalghatgi, G. T., Hildingsson, L., Harrison, A. J., Johansson, B., "Autoignition quality of gasoline fuels in partially premixed combustion in diesel engines," Proceedings of the 
http://dx.doi.org/10.1016/j.proci.2010.07.007. 


\section{List of Figures}

Figure 1. Engine Layout [22]

Figure 2. In-Cylinder Pressure at 3 bar, 1200 RPM (a) Gasoline MBT (b) Fuels MBT

Figure 3. Mass Fraction Burned (MFB) - 3 bar, 1200 RPM, $\Phi=1$ at Gasoline MBT (top) and Fuels MBT (bottom)

Figure 4. (a) 0-10\% MFB Duration, (b) CA50 Location, (c) 10-90\% MFB Duration

Figure 5. 0-10\% MFB Duration (top), CA50 Location (middle), 10-90\% MFB Duration (bottom) at 1200 RPM, 3 bar BMEP

Figure 6. BSFC at 1200 RPM, 3 bar BMEP

Figure 7. (a) Gasoline Equivalent BSFC; (b) BTE at 1200 RPM, 3 bar BMEP

Figure 8 . EGT at $\Phi=1$, at $3 \& 5$ bar BMEP.

Figure 9. Unburnt Hydrocarbons (UHC) emissions at (a) gasoline MBT, $\Phi=1$; (b) fuels MBT, 3 bar BMEP (bottom)

Figure 10. Carbon Monoxide (CO) emissions at (a) gasoline MBT, $\Phi=1$; (b) fuels MBT, 3 bar BMEP (bottom)

Figure 11. Nitrogen oxide (NOx) emissions at (a) gasoline MBT, $\Phi=1$; (b) fuels MBT, 3 bar BMEP (bottom)

\section{$\underline{\text { List of Tables }}$}

Table 1. Engine Specifications

Table 2. Properties of Individual Fuels [29, 44]

Table 3. Properties of Fuel Blends (Calculated)

Table 4. Test Conditions

Table 5. Fuel MBTs 
Figures:

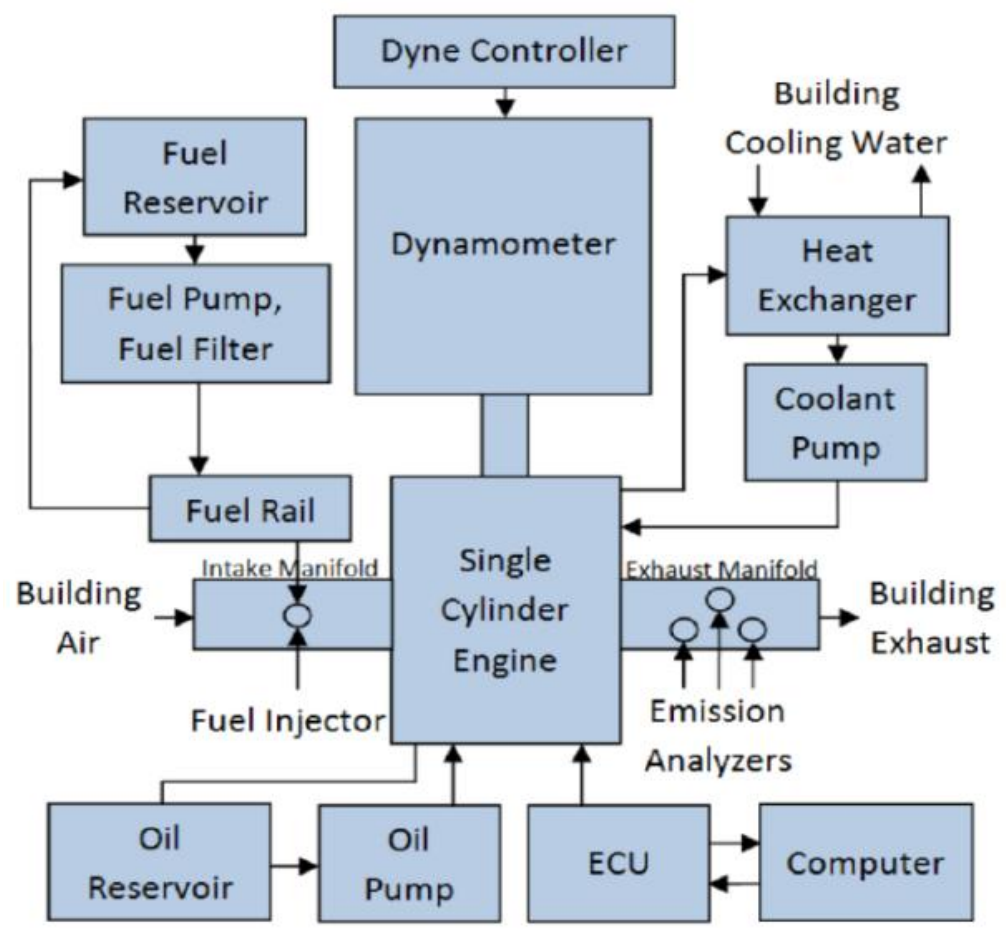

Figure 1. Engine Layout [22] 


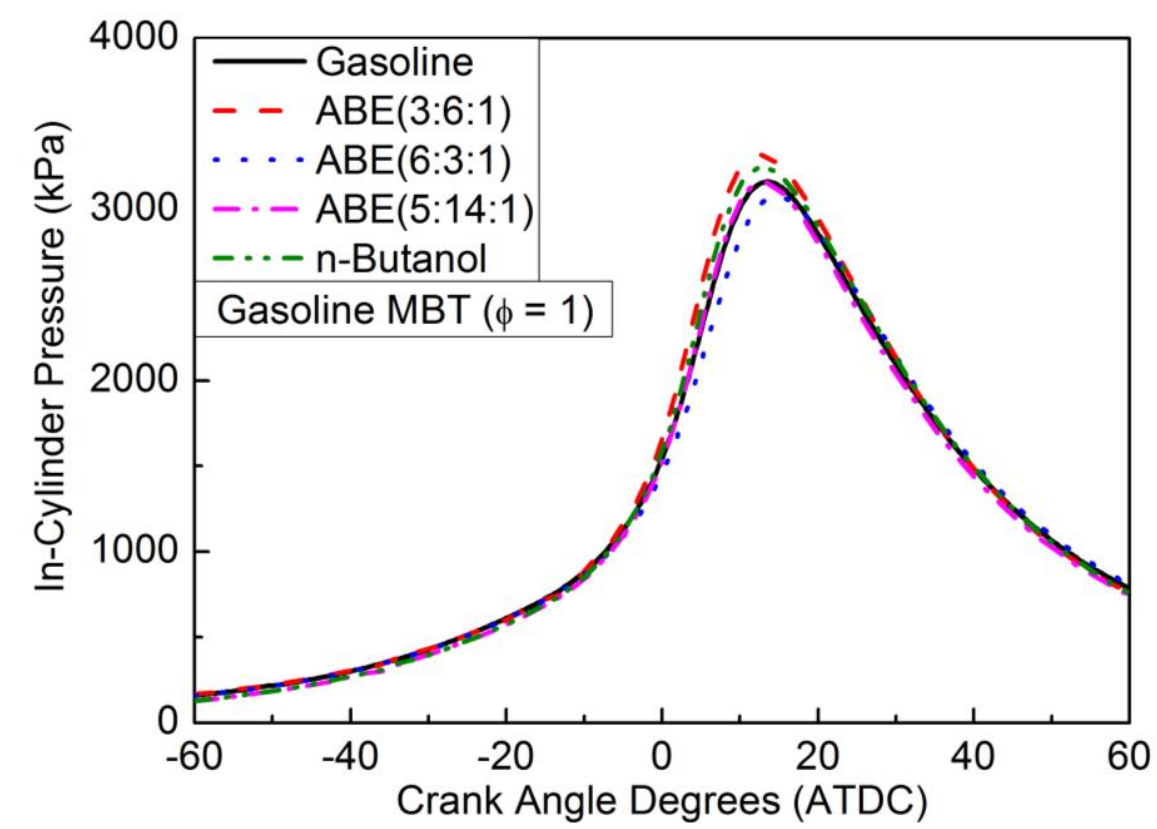

(a)

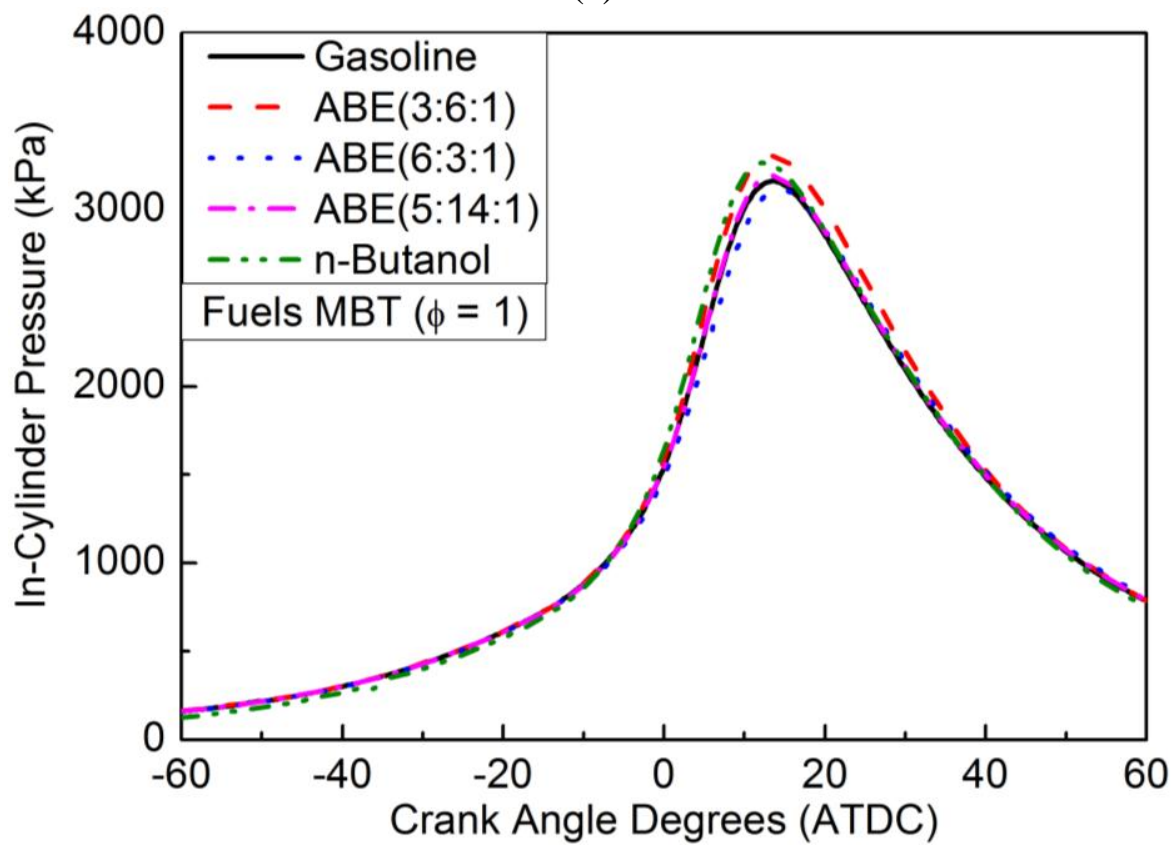

(b)

Figure 2. In-Cylinder Pressure at 3 bar, 1200 RPM (a) Gasoline MBT (b) Fuels MBT 

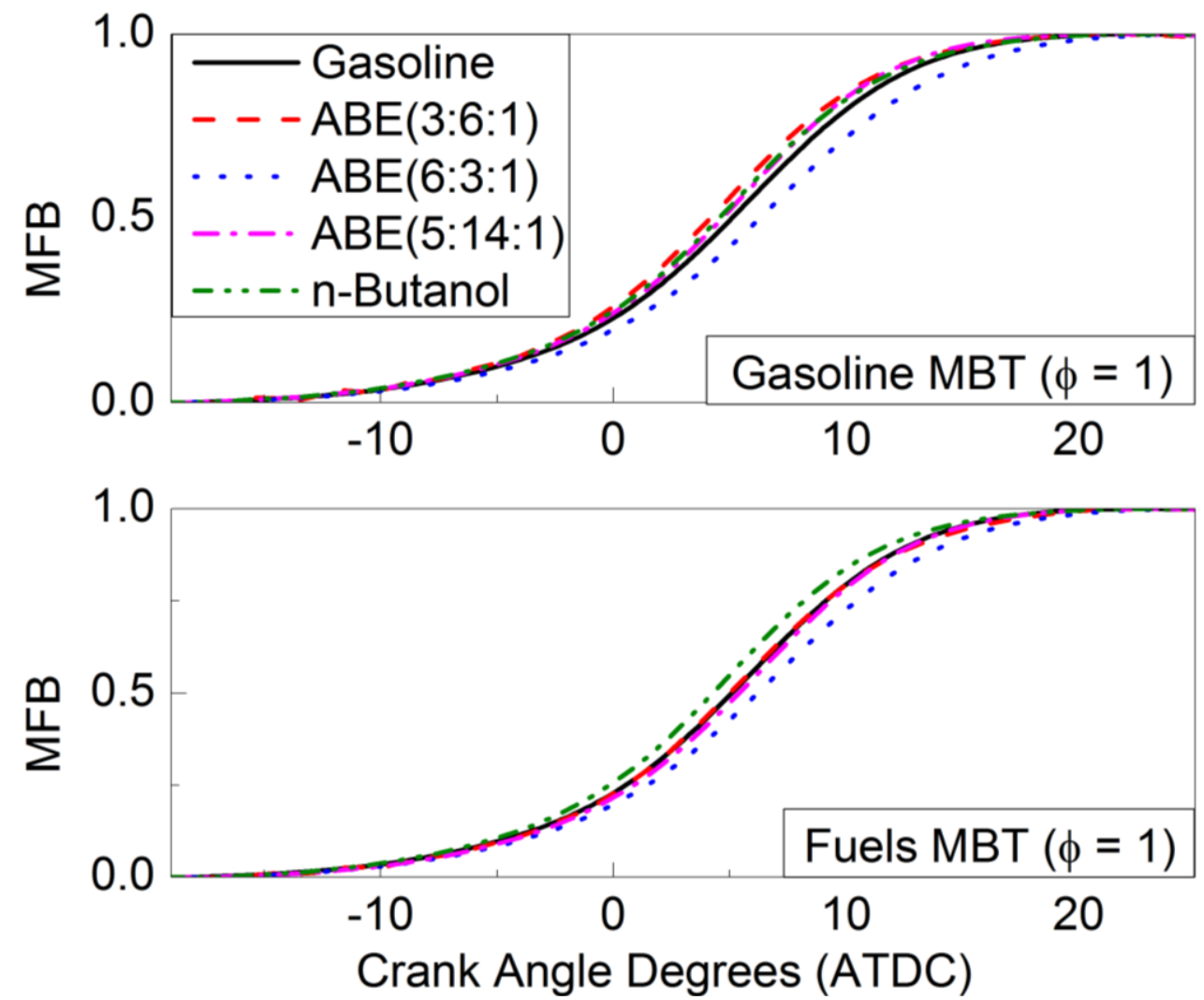

Figure 3. Mass Fraction Burned (MFB) - 3 bar, 1200 RPM, $\Phi=1$ at Gasoline MBT (top) and Fuels MBT (bottom) 


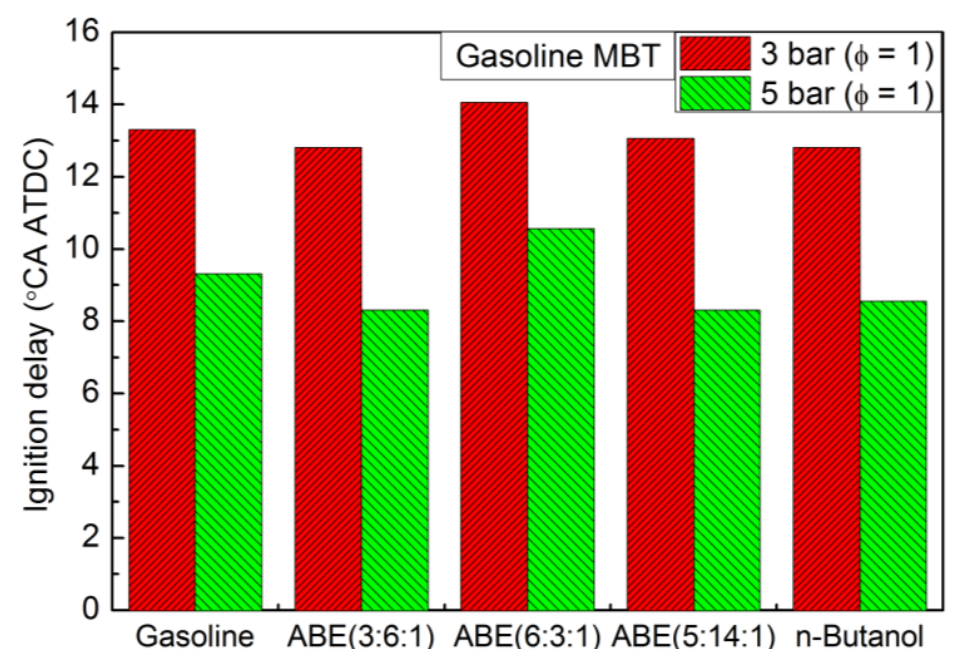

(a)

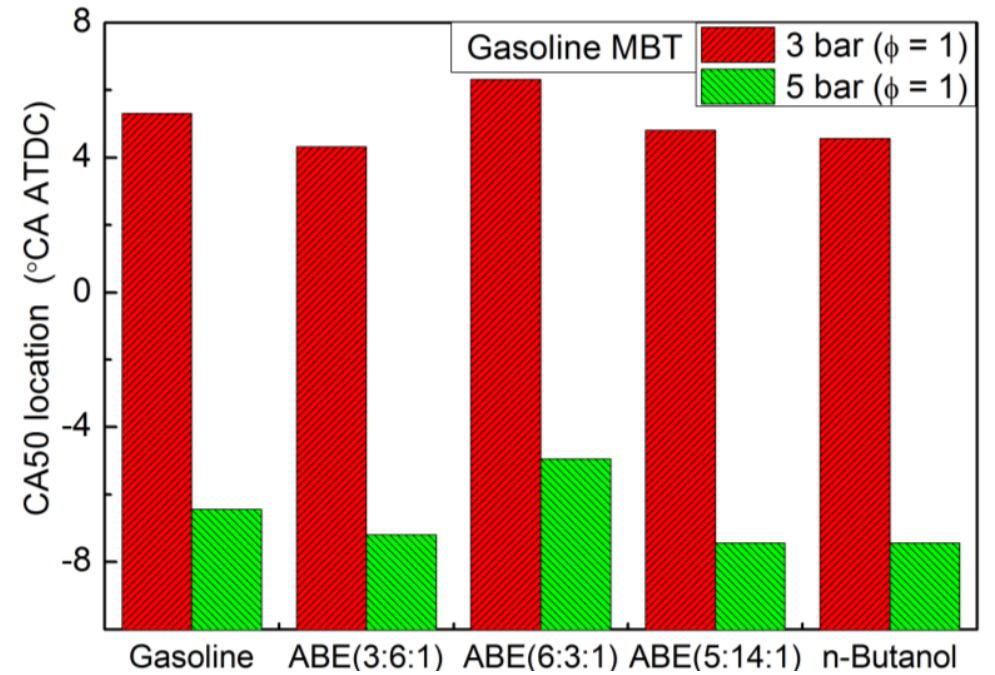

(b)

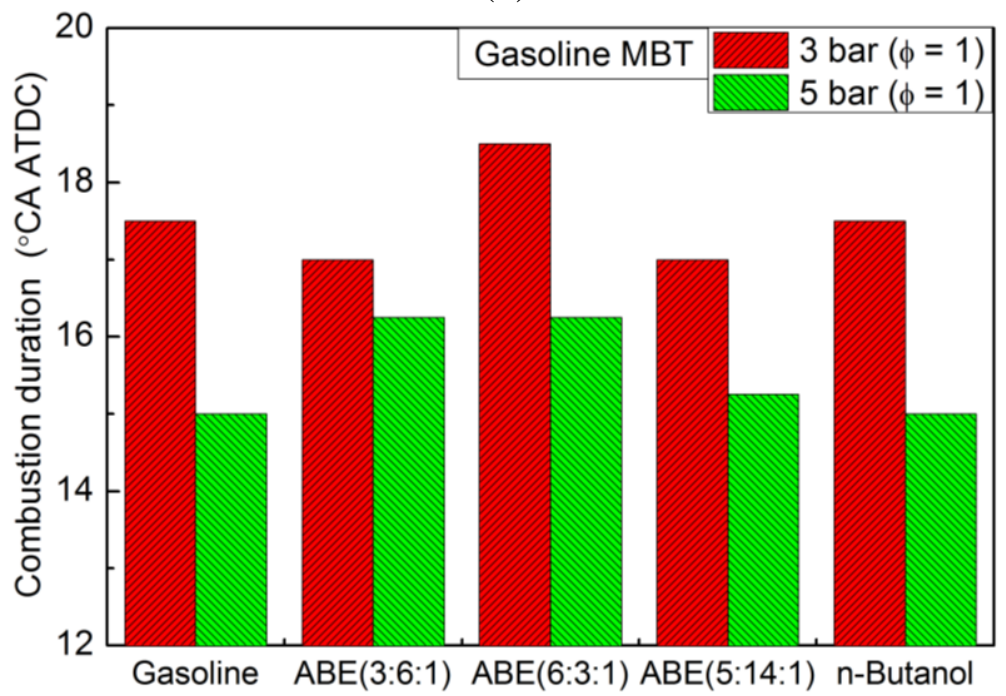

(c)

Figure 4. (a) 0-10\% MFB Duration, (b) CA50 Location, (c) 10-90\% MFB Duration 

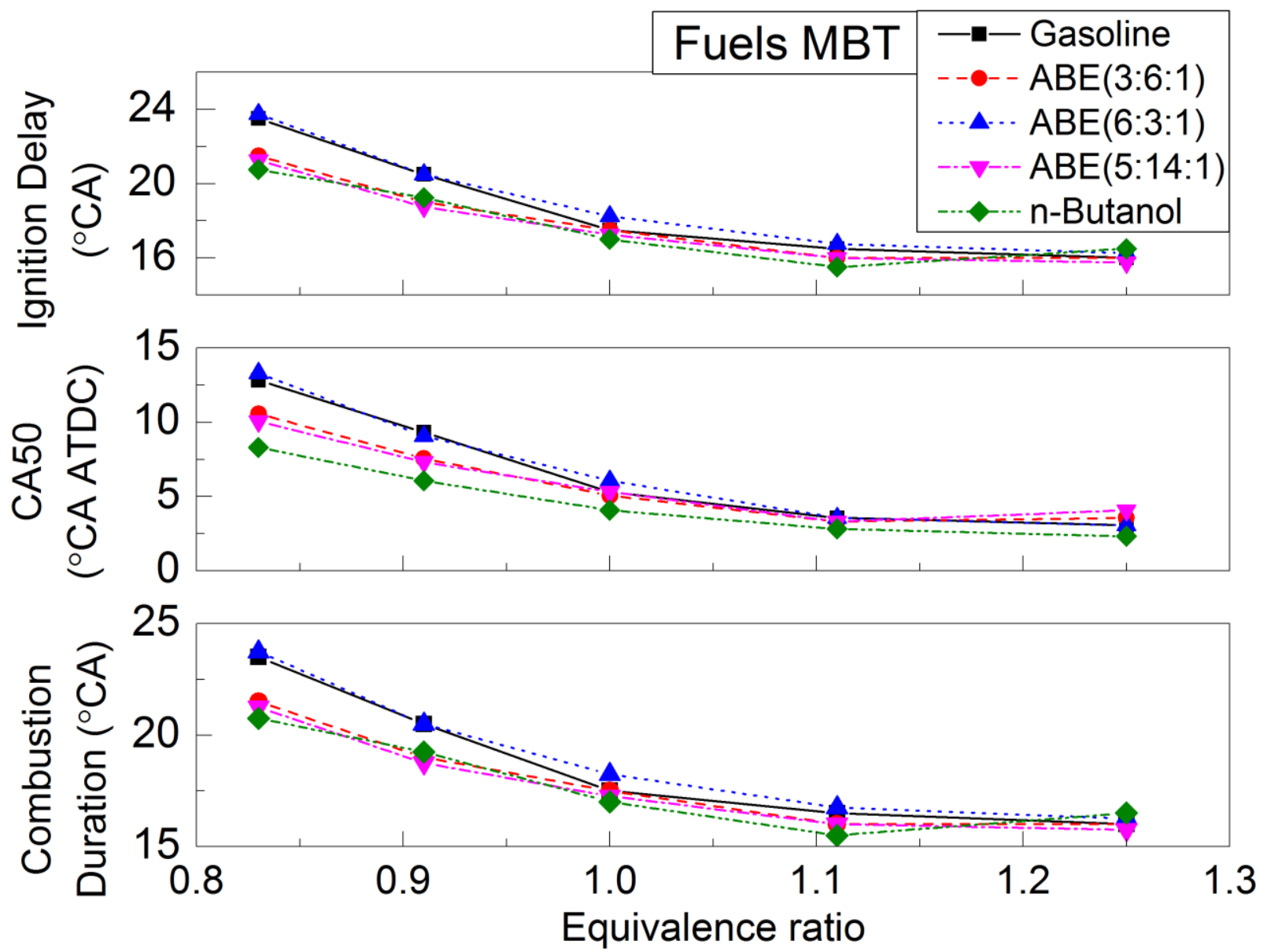

Figure 5. 0-10\% MFB Duration (top), CA50 Location (middle), 10-90\% MFB Duration (bottom) at 1200 RPM, 3 bar BMEP 


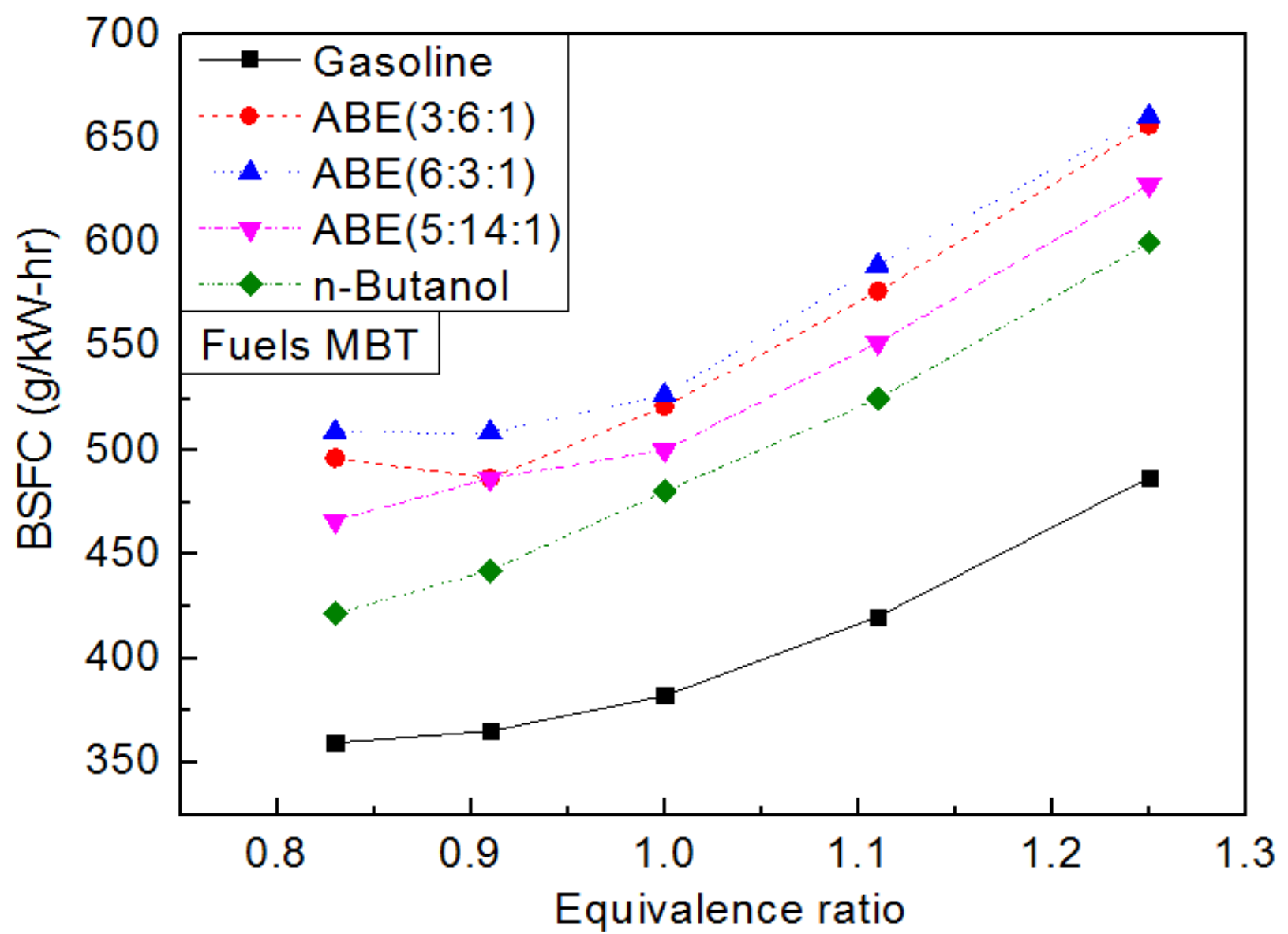

Figure 6. BSFC at 1200 RPM, 3 bar BMEP 


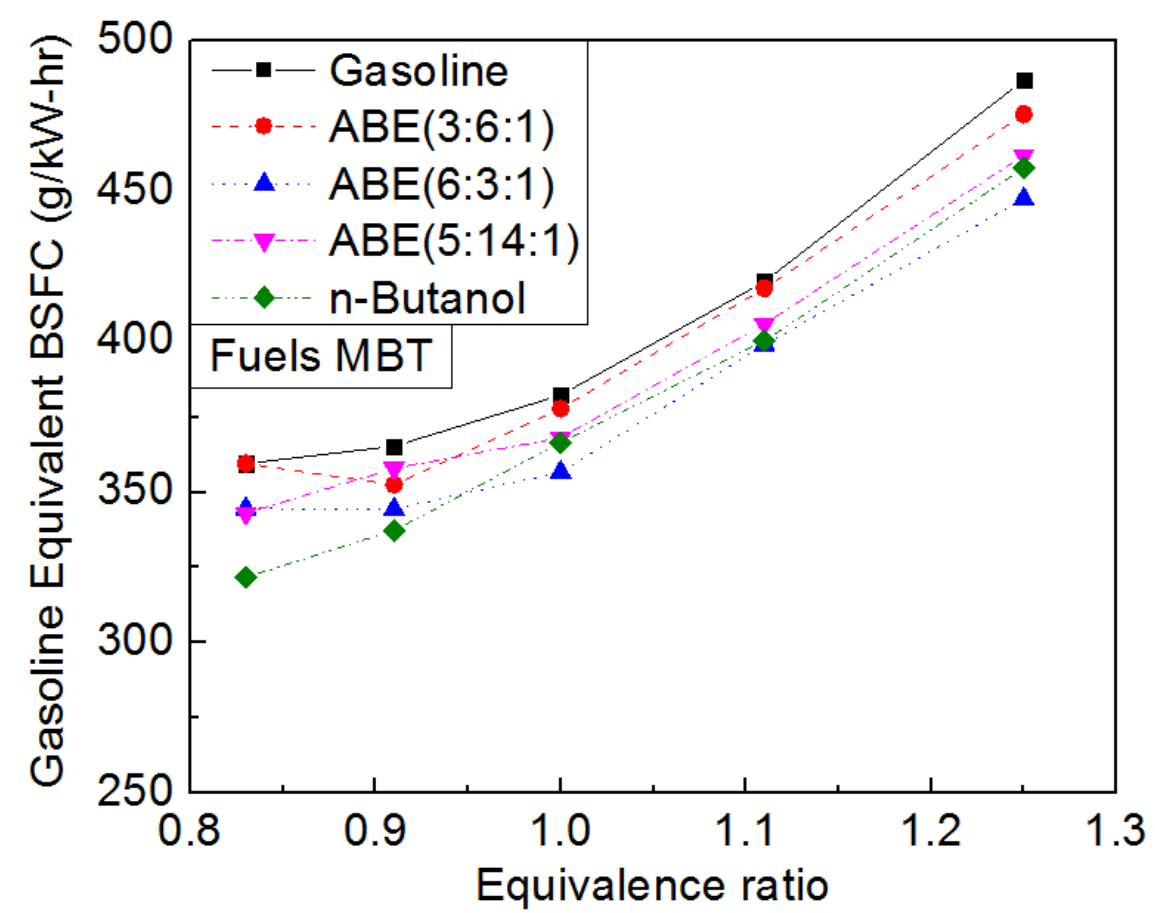

(a)

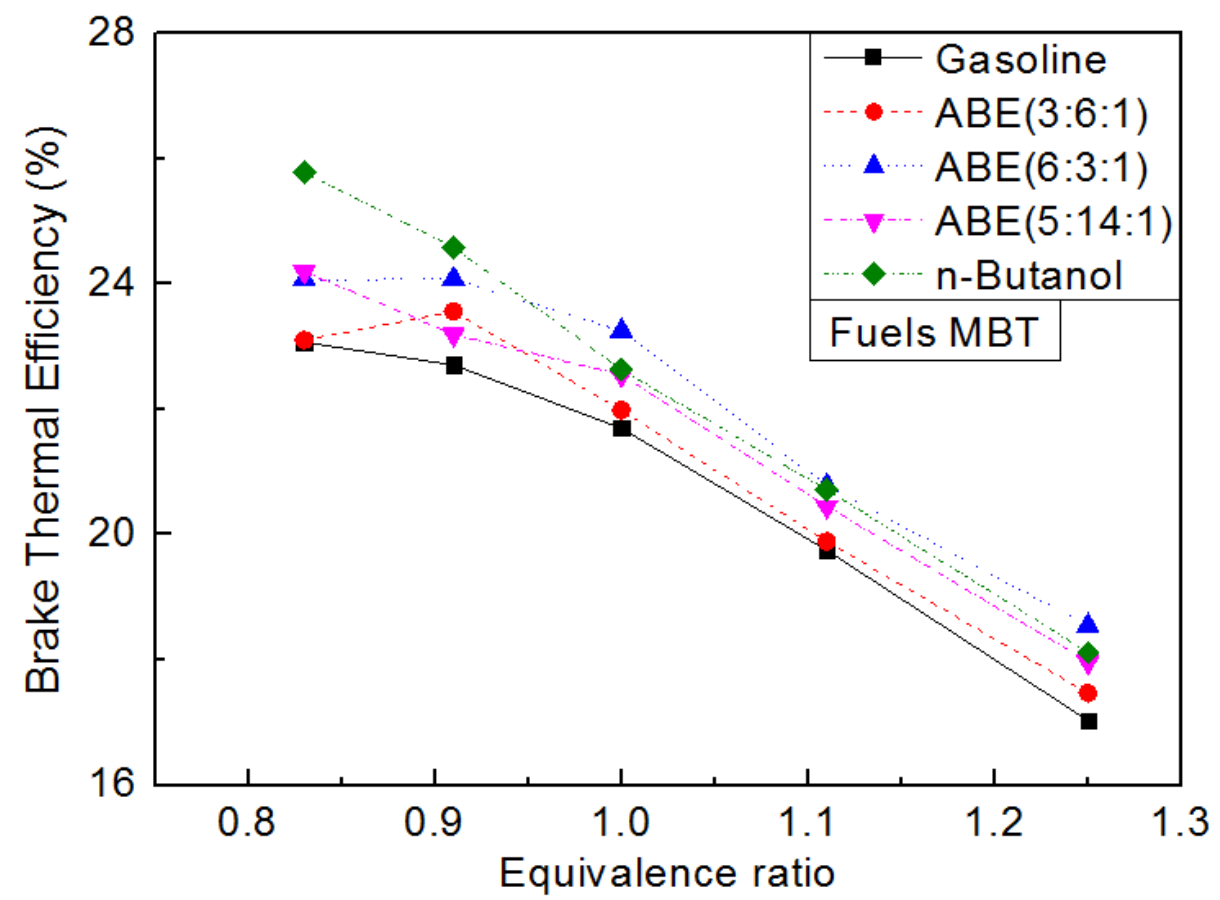

(b)

Figure 7. (a) GE BSFC, (b) BTE at 1200 RPM, 3 bar BMEP 


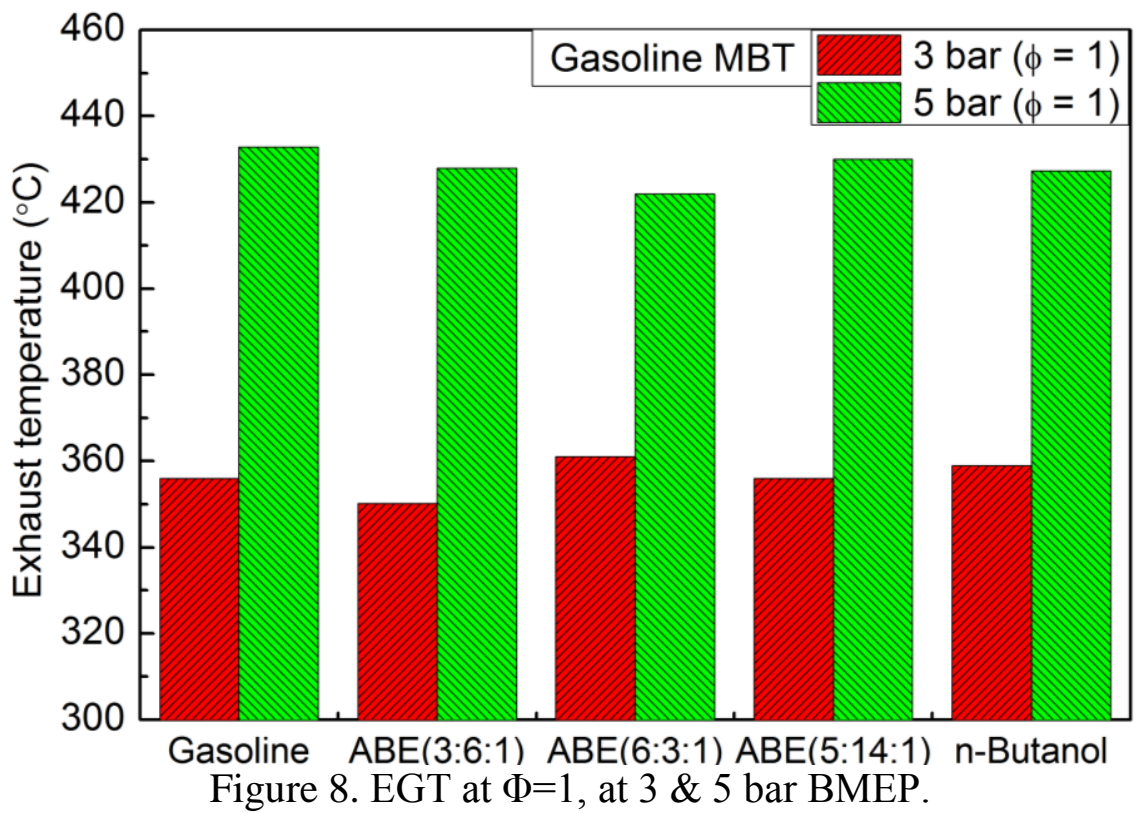

Page 33 of 38 


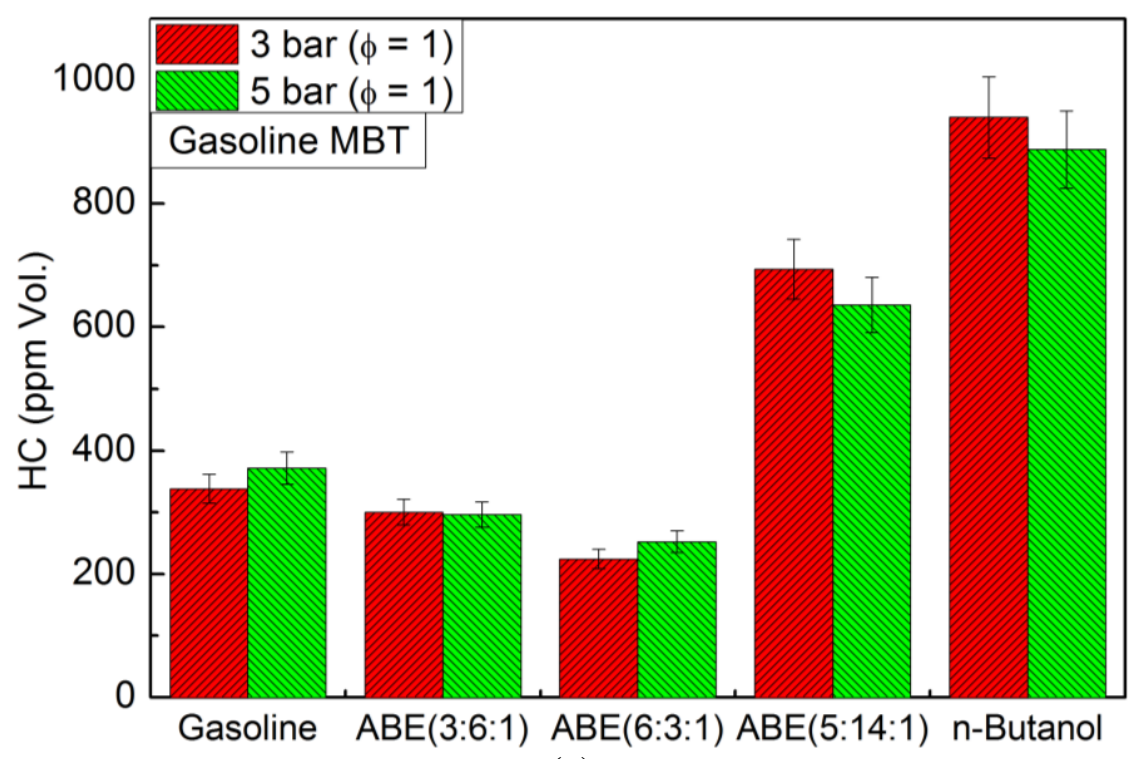

(a)

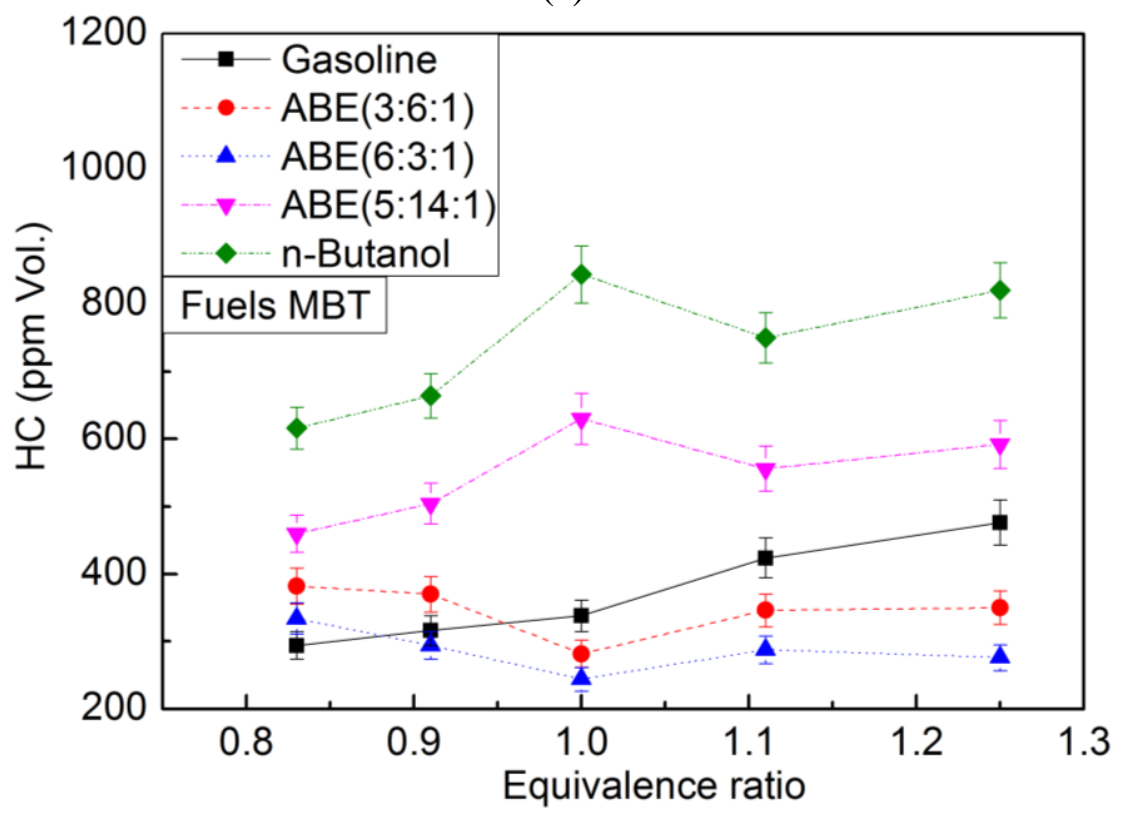

(b)

Figure 9. Unburnt Hydrocarbons (UHC) emissions at (a) gasoline MBT, $\Phi=1$; (b) fuels MBT, 3 bar BMEP (bottom) 


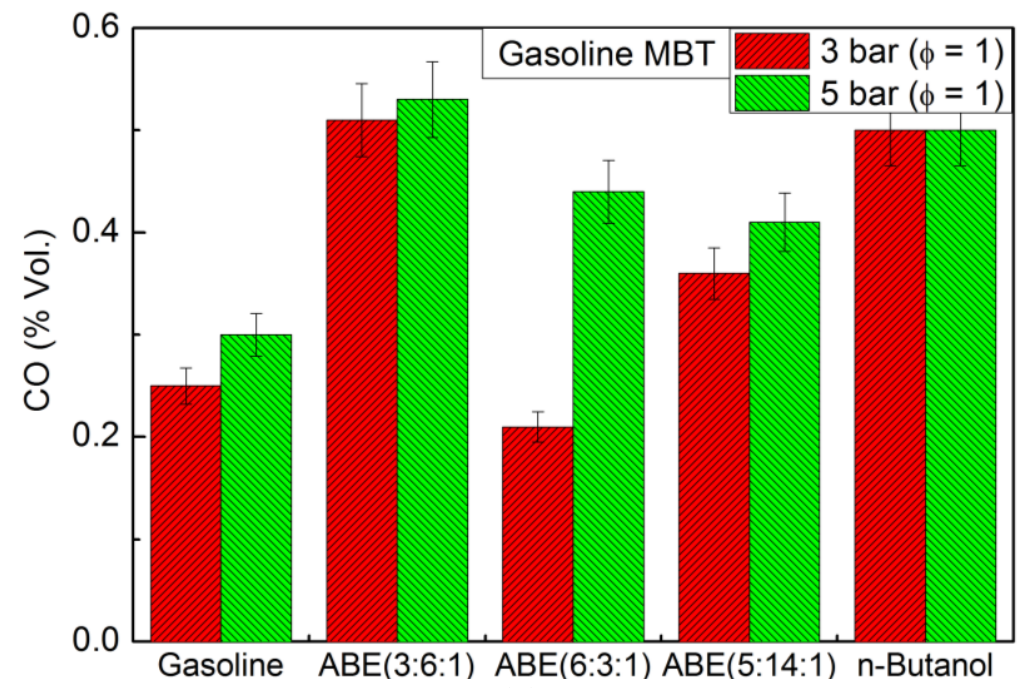

(a)

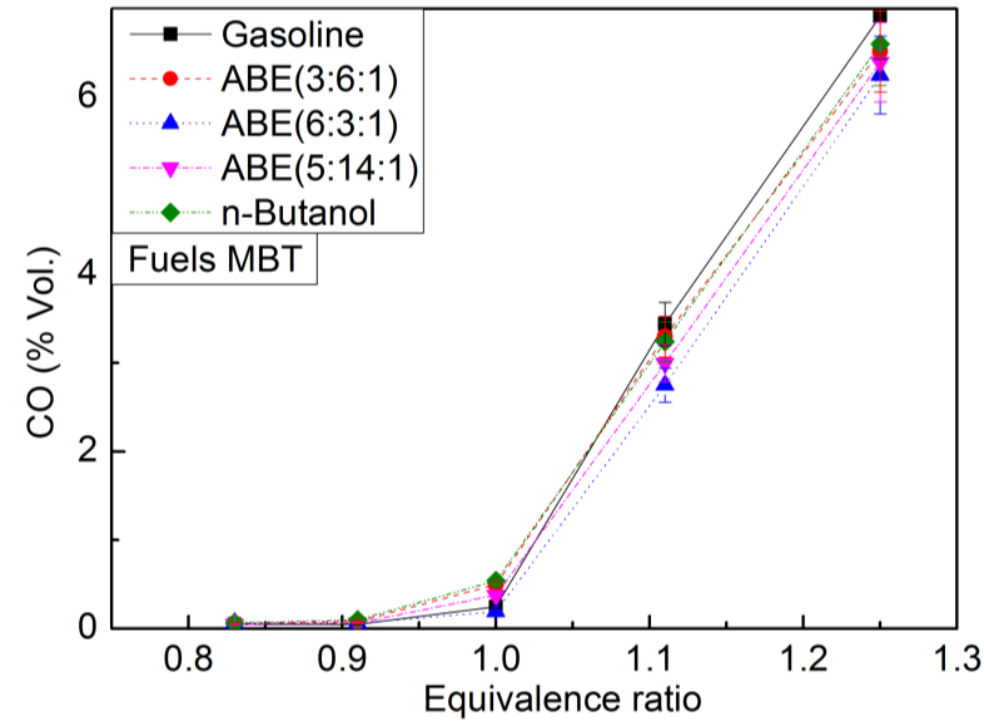

(b)

Figure 10. Carbon Monoxide (CO) emissions at (a) gasoline MBT, $\Phi=1$; (b) fuels MBT, 3 bar BMEP (bottom) 


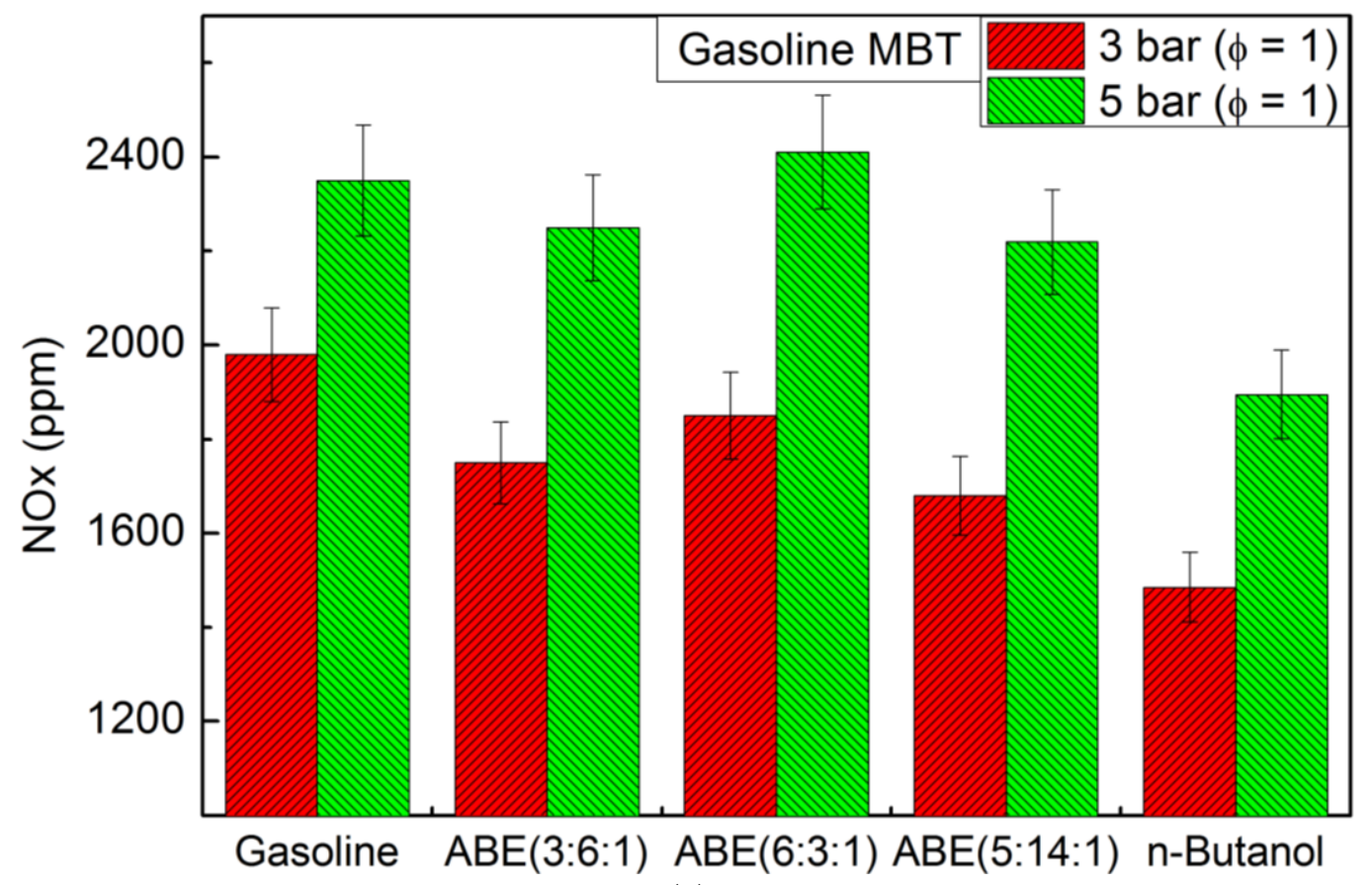

(a)

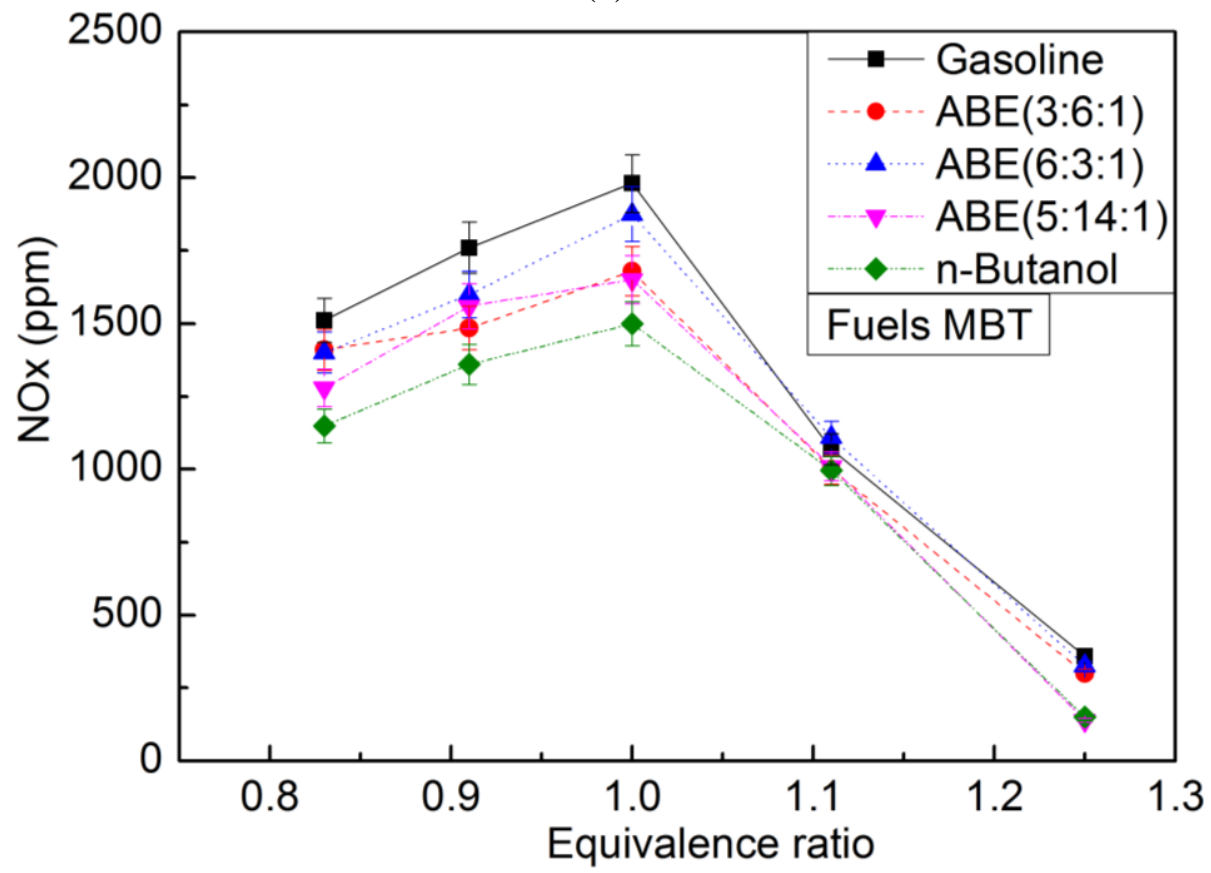

(b)

Figure 11. Nitrogen oxide (NOx) emissions at (a) gasoline MBT, $\Phi=1$; (b) fuels MBT, 3 bar BMEP (bottom) 
Tables:

Table 1. Engine Specifications

\begin{tabular}{|l|l|}
\hline Displaced volume & $575 \mathrm{cc}$ \\
\hline Stroke & $90.1 \mathrm{~mm}$ \\
\hline Bore & $90.3 \mathrm{~mm}$ \\
\hline Connecting Rod & $150.7 \mathrm{~mm}$ \\
\hline Compression ratio & $9.6: 1$ \\
\hline Number of Valves & 4 \\
\hline Fuel Injection & Port Fuel Injection \\
\hline
\end{tabular}

Table 2. Properties of Individual Fuels [29, 44]

\begin{tabular}{|c|c|c|c|c|}
\hline Parameter & Gasoline & Ethanol & Butanol & Acetone \\
\hline Chemical Formula & $\mathrm{C}_{4}-\mathrm{C}_{12}$ & $\mathrm{C}_{2} \mathrm{H}_{5} \mathrm{OH}$ & $\mathrm{C}_{4} \mathrm{H}_{9} \mathrm{OH}$ & $\mathrm{C}_{3} \mathrm{H}_{6} \mathrm{O}$ \\
\hline Composition $(\mathrm{C}, \mathrm{H}, \mathrm{O})$ (Mass \%) & $86,14,0$ & $52,13,35$ & $65,13.5,21.5$ & $62,10.5,27.5$ \\
\hline Lower Heating Value $(\mathrm{MJ} / \mathrm{kg})$ & 43.4 & 26.8 & 33.1 & 29.6 \\
\hline Density $\left(\mathrm{kg} / \mathrm{m}^{3}\right)$ & $715-765$ & 790 & 810 & 790 \\
\hline Energy Density $(\mathrm{MJ} / \mathrm{l})$ & 32.20 & 21.17 & 26.81 & 23.38 \\
\hline Octane Number $((\mathrm{R}+\mathrm{M}) / 2)$ & 90 & 100 & 87 & 117 \\
\hline Boiling Temperature $\left({ }^{\circ} \mathrm{C}\right)$ & $25-215$ & 78 & 118 & 56.2 \\
\hline $\begin{array}{l}\text { Latent Heat of Vaporization }\left(25^{\circ} \mathrm{C}\right) \\
(\mathrm{kJ} / \mathrm{kg})\end{array}$ & $380-500$ & 904 & 716 & 518 \\
\hline Self-Ignition Temperature $\left({ }^{\circ} \mathrm{C}\right)$ & $\sim 300$ & 420 & 343 & 465 \\
\hline Stoichiometric Air/Fuel Ratio & 14.7 & 9.0 & 11.2 & 9.5 \\
\hline Laminar Flame Speed (LFS) $(\mathrm{cm} / \mathrm{s})$ & $\sim 33^{\mathrm{a}}$ & $-39^{\mathrm{a}}$ & $\sim 48^{\mathrm{b}}$ & $\sim 34^{\mathrm{c}}$ \\
\hline Mixture Calorific Value $\left(\mathrm{MJ} / \mathrm{m}^{3}\right)$ & 3.72 & 3.85 & 3.82 & 4.04 \\
\hline $\begin{array}{l}\text { Ignition Limits in Air (vol. \%) } \\
\text { [Lower-Upper] }\end{array}$ & $0.6-8$ & $3.5-15$ & $1.4-11.2$ & $2.6-12.8$ \\
\hline $\begin{array}{l}\text { Solubility in Water at } 20^{\circ} \mathrm{C}(\mathrm{ml} / 100 \\
\left.\mathrm{ml} \mathrm{H}_{2} \mathrm{O}\right)\end{array}$ & $<0.1$ & $\begin{array}{l}\text { Fully } \\
\text { Miscible }\end{array}$ & 7.7 & $\begin{array}{l}\text { Fully } \\
\text { Miscible }\end{array}$ \\
\hline
\end{tabular}


Table 3. Properties of Fuel Blends (Calculated)

\begin{tabular}{|l|l|l|l|l|l|l|}
\hline Fuel Type & $\begin{array}{l}\text { Specific } \\
\text { Gravity }\end{array}$ & $\begin{array}{l}\text { Lower } \\
\text { Heating } \\
\text { Value (LHV) } \\
(\mathbf{M J} / \mathbf{k g})\end{array}$ & $\begin{array}{l}\text { Energy } \\
\text { Density } \\
\text { (MJ/l) }\end{array}$ & $\begin{array}{l}\text { Stoichiometric } \\
\text { Air/Fuel Ratio }\end{array}$ & $\begin{array}{l}\text { Butanol } \\
\text { Vol. \% }\end{array}$ & $\begin{array}{l}\text { Acetone } \\
\text { Vol. \% }\end{array}$ \\
\hline Gasoline & 0.739 & 43.44 & 31.68 & 14.65 & 0 & 0 \\
\hline ABE(6:3:1) & 0.796 & 30.3 & 24.1 & 9.94 & 30 & 60 \\
\hline ABE(3:6:1) & 0.802 & 31.45 & 25.22 & 10.36 & 60 & 30 \\
\hline ABE(5:14:1) & 0.804 & 31.93 & 25.67 & 10.64 & 70 & 25 \\
\hline n-Butanol & 0.810 & 33.1 & 26.81 & 11.06 & 100 & 0 \\
\hline
\end{tabular}

Table 4. Test Conditions

\begin{tabular}{|l|l|}
\hline Engine Speed & $1200 \mathrm{RPM}$ \\
\hline Load (BMEP) & $3 \mathrm{bar}, 5 \mathrm{bar}$ \\
\hline Equivalence Ratio & $0.83-1.25$ \\
\hline Spark Timing & Gasoline MBT, Fuel MBT \\
\hline Fuel Pressure & $3 \mathrm{bar}$ \\
\hline
\end{tabular}

Table 5. Fuel MBTs

\begin{tabular}{|l|l|llll|}
\hline Fuel & MBT @ 3 bar BMEP & MBT @ & 5 & bar \\
\hline Gasoline & $18^{\circ}$ BTDC & $24^{\circ}$ BTDC & \\
\hline ABE(6:3:1) & 17.7 & 23.6 & & \\
\hline ABE(3:6:1) & 17.6 & 23.5 & & \\
\hline ABE(5:14:1) & 17.5 & 23.4 & & \\
\hline n-Butanol & 17.4 & 23.3 & & \\
\hline
\end{tabular}

